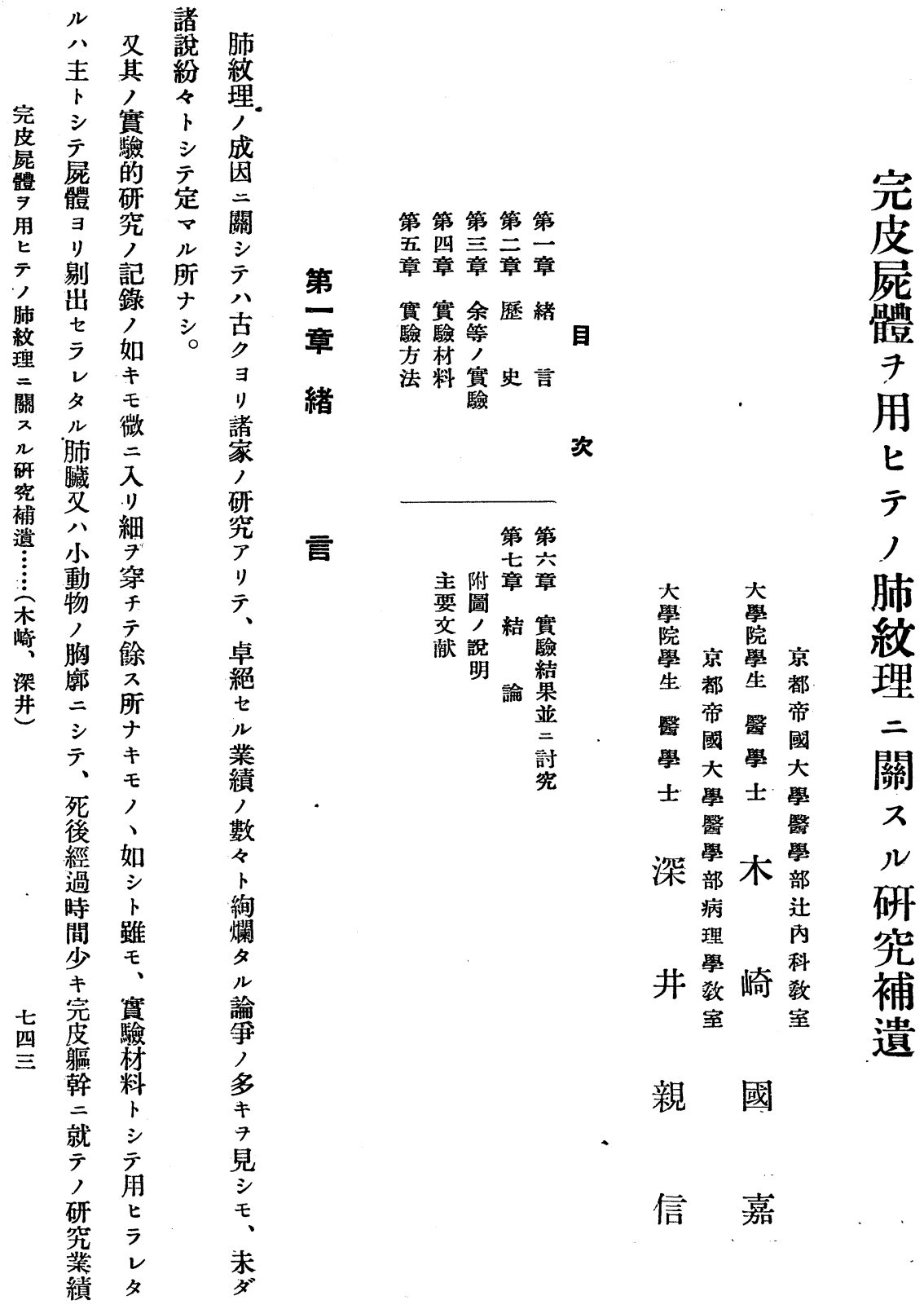




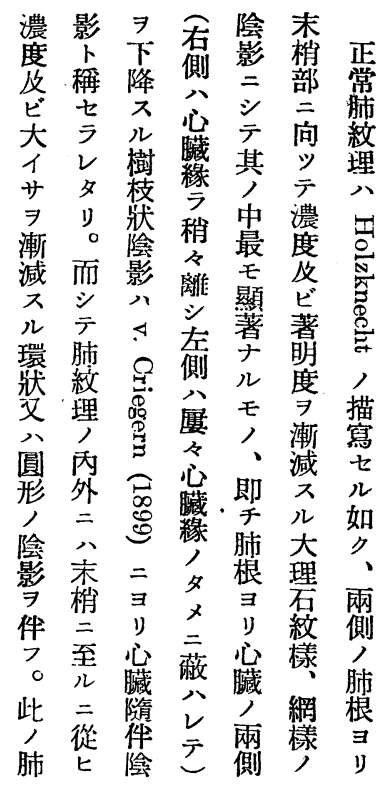

形今ナデナナ紋 う其論 ス影質關

儿 跡 $\exists$ 嬂 形 $\exists$ 劣

今 $\rightrightarrows$ 展烈成捕

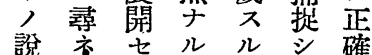

$\exists シ$ 㥕力不ナ

唱 $三$ 求, 能儿

導 $\&$ 分問儿理

法り早題古解

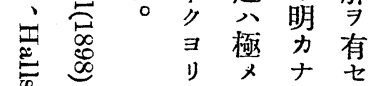

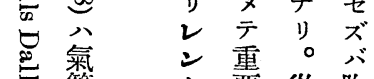

党覃要從胸

綮 ぶ

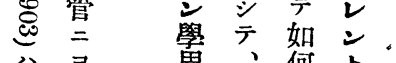

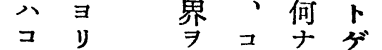

レコ 駱レ ル

ᄀ人

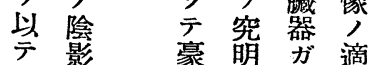

體影蒙 明ガ適
タ實余テカ題ルナ

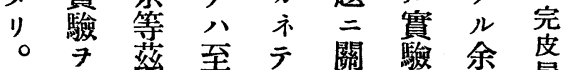

反 難 此 シ 動 等 屍

覆相ナ程テ物, 體 シ提ル人余二末用

、携 尹 研 等 於 ダ ヒ

唒 ス惟究八テ見テ コ機り 待直得聞向 子會。徸後ルぜ紋

補子琵實ル理

歴 7 得 屁䲆所關

ニ モ 體ノた オ

諸ル、、結们ル

種 7 實 就 果 $○$ 研

人上驗亏 7 胸究

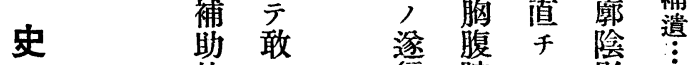

的 $テ$ 行貯二影

䨘 コ等人烄

噞 閳當 7 體 影 崎

結 題

果 7 八衍度茾

7 追 臨 ル シ 外

以究床事 方視

テ 七 ナ論

シリレクズル

肺即襍心出

紋 千 齐 7 余肺

理完 V 行等 臟

皮學 フ

成㡾卢檪

因體病音服方

關用 理 必 要得睯吉

ス

ルテ學 ル

說二, 痛ナ公

二諸 密感リ緎

就蒙接 ス。細

テノナルノナ

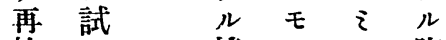

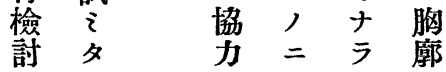




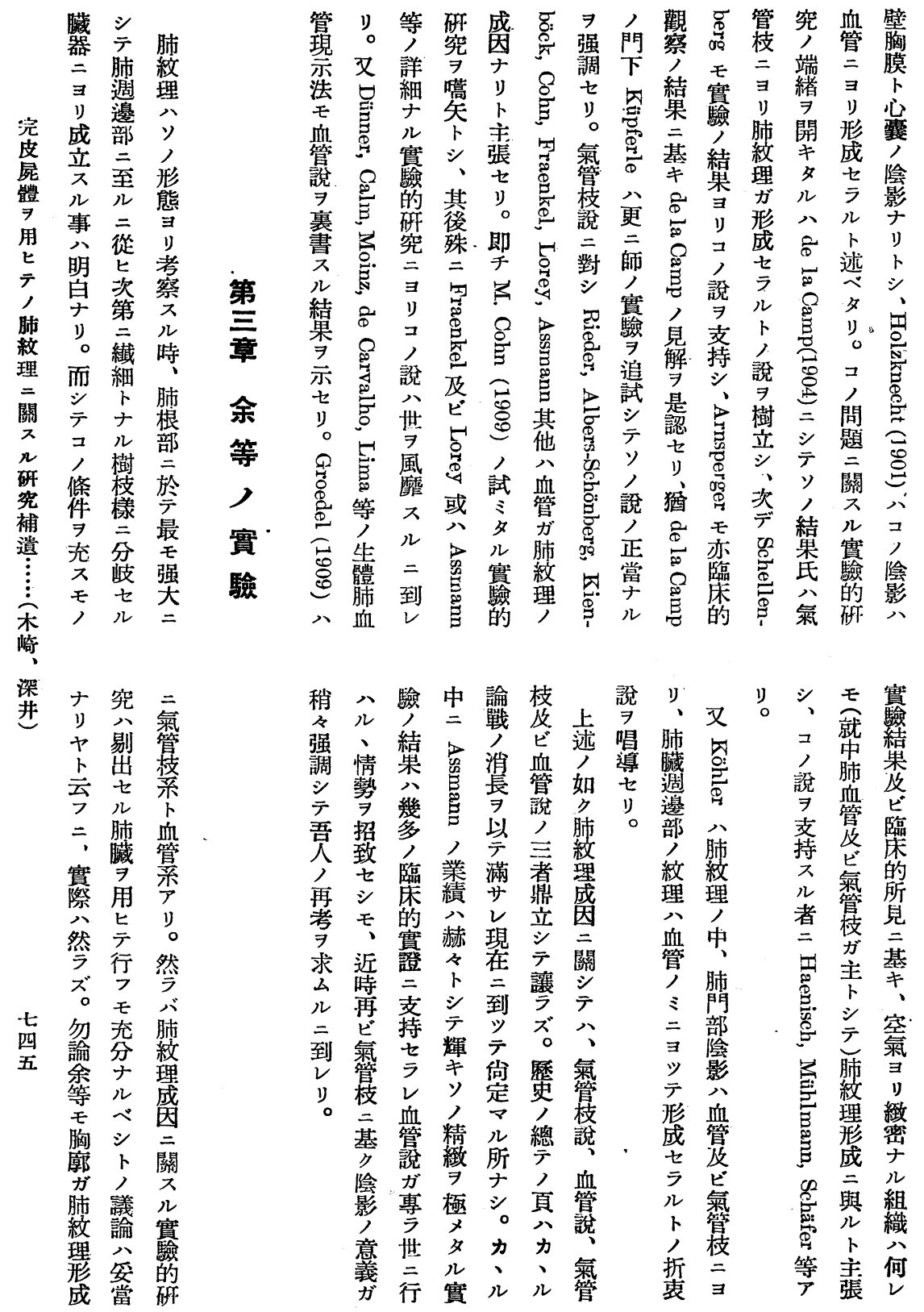




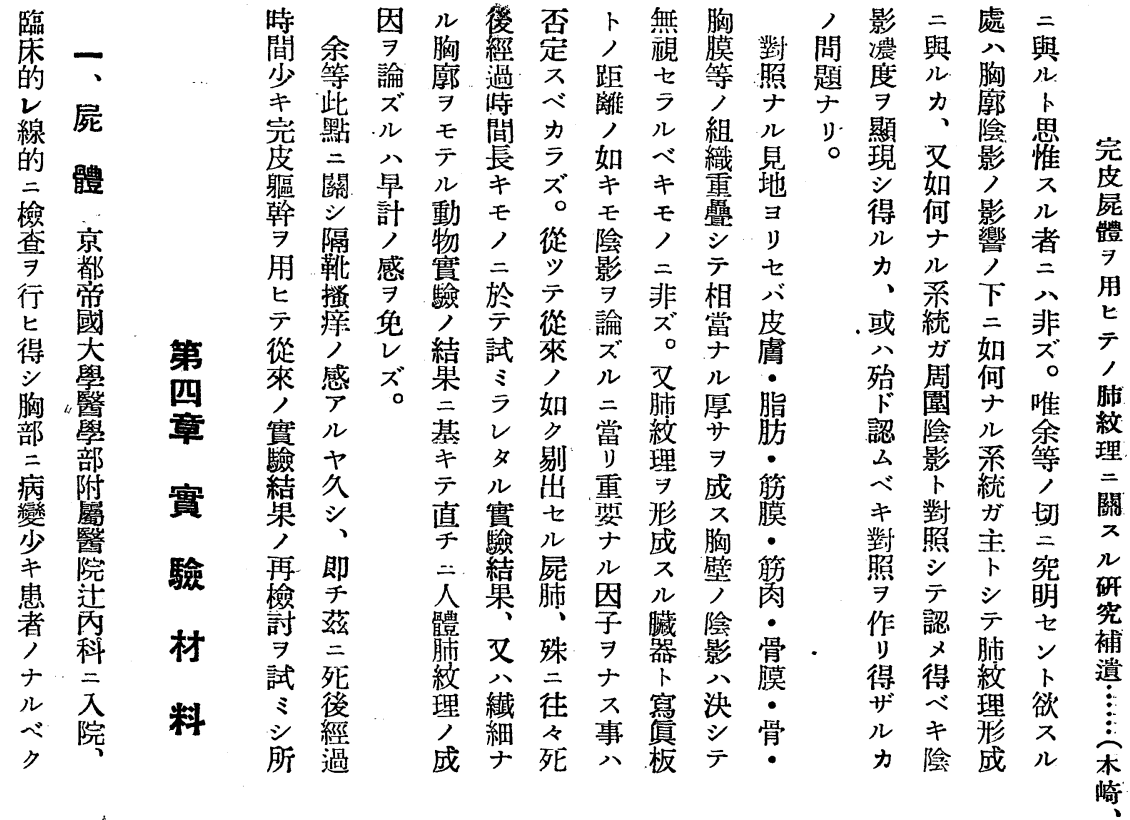

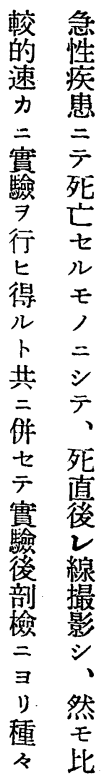

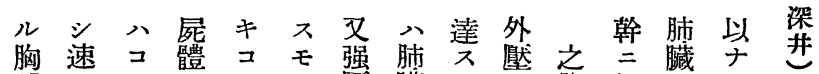

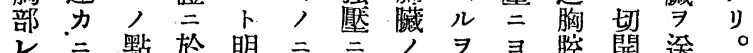
線實 $=テ$ 瞭 $ア コ$ 萎以り

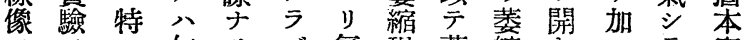
$\exists \rightrightarrows=$ 勿りズ氣程著縮キフテ實 檢行留論。、慗度梦ステル膨驗 討 フ意生余必枝八刀。肺如隆煘

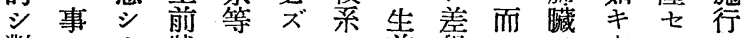
對 $=$ 狀八ヤ三前翼モ $\Rightarrow$ 方 照努儿態此血㴡, 另べ方管载呼生, 出玉ルテ 七シク相點䒺 ス氯ズ際ス原如八 リ、、當二氣ル狱ルノル則丰從

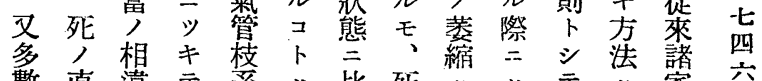
數直違テ系八比死 八八テ父

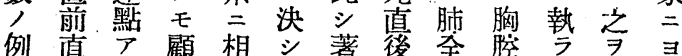
二後ル慮當テジ容內ザ行り 就 =

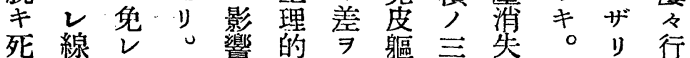

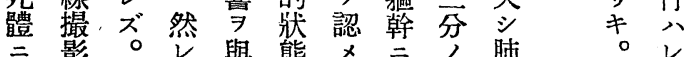
於影余、ド與態

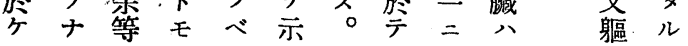


端卜注卜流股 1 二心肺二

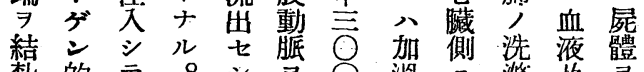

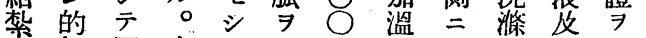

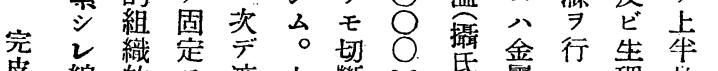

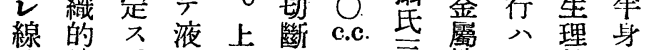

檢追 07 記 $シ 7$ 辛管 $ン$ 的 $\exists$ 血

香究 ソ流

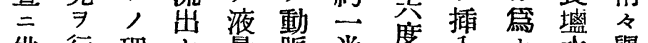

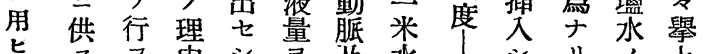

テ

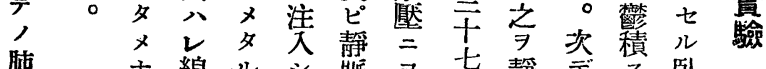

理

閶

r

磁

管

補

道

查

粱

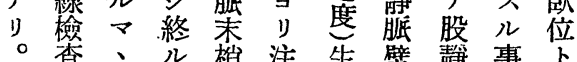

固後約頃部资理上胍

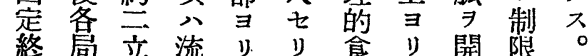

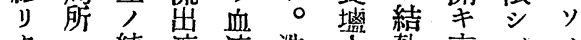

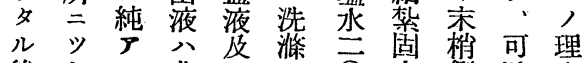

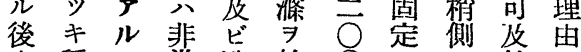

血種 コ常洗 始

管令

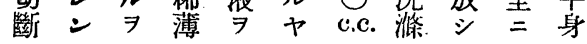

梁

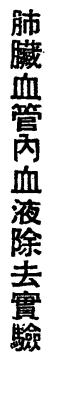

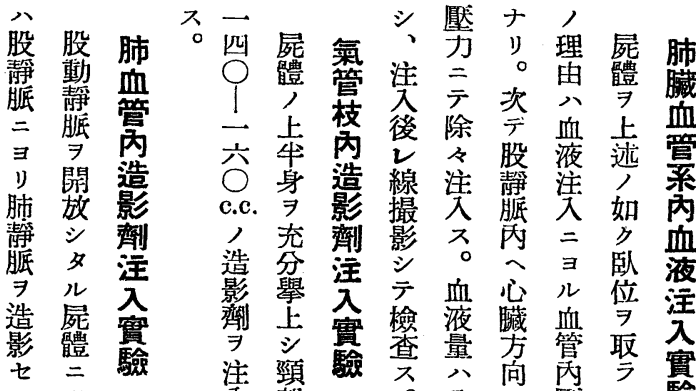

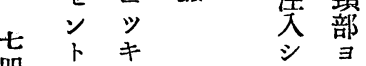

四 ス 脑

ル 動

時 质

股 造

動影

ヨ ン

む

臟 ル
十篦

至 官

十

五 金

後 管

ᄂ $\Rightarrow$

線 挿

撮 入
八二獎 シ 驗

0 向上

(1) 年 股

○ 7 動

方 前出瑟

至 記 得

( 7 リ

宁約 防 開

c.c. 米 グ
○血 夜 限 恃
氐紧二實

度气血果

睬頭液檢

器約實得

二

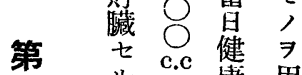

五 儿 c.c 亲用

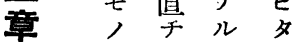

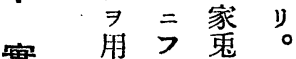

䨘七亿文

驗 リ リ 動

方除 寻

去瀉

法

指 $=$

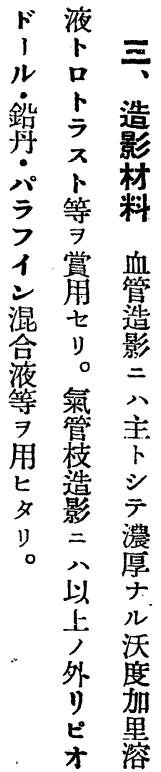


ス恐說ク八關

○今明屍一先 ス 余

然ク七體般ジル等

レ撮 $三 二=$ 死論八

ト 影レ於陰後述以

モ ガ、 $\overline{7}$ 影

。極 血肺濃撮進了

- $x$ 管 紋 度 影 $x$ 如

テ 説理 增 七ンキ キ

尺死了劣加有微實

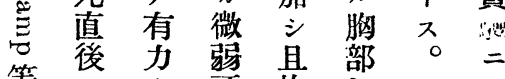

等 後力弱 县部 0 当

ガ行 ル 明等湶

賽 少瞭 化像

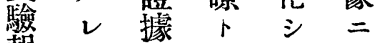

報夕大ナ肺就

告ル—ル緅テ

中二ッ 中理肺

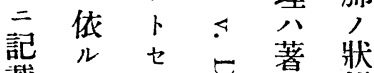

載 今 ラ 导著態

ルクレ寻》 7

屍㮐》忿溦見

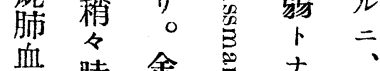

血管 時 余等 导ナ

ガ間 等 等 、 既

全 經 提 但 諸

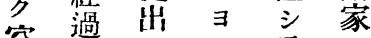

空虑七り唒二

虚テル 血

卜撮圖葆》リ

ナ影 二 ガ 樹 記

ル晾於向䓩述

如 テ 部 狀

如圖 肺肺二

事二紋動 分

事於理脈跂夕

既亏 学

二肺當脫 狀多

紋䐯出態生

理 瞭

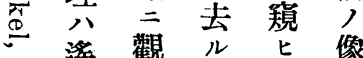

巨遙 憼 ル

怘

等減得少肺

二弱 ㅅ

先

淮

諸

筫

菜

續

龃

比

シ

Z

$=$

考

按

7

加

$\hat{\bar{\tau}}$

肺

紋

理

成

[犬]
態方ッ數卜, 向

並法以, 丰造二

二三上屍八影向

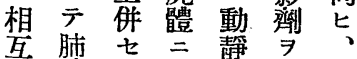

間動 行就胍約前完

關脈七試同米者㧞

係肺同ミ時人ラ 體

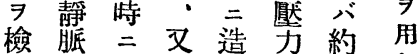

第 索

六。枝系例コ注

章特分氣云卜售紋

得定各管於 7 不苛理

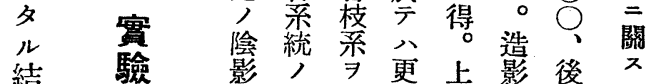

笨結 個現三記旅著几

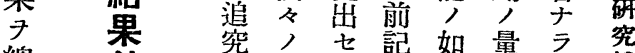

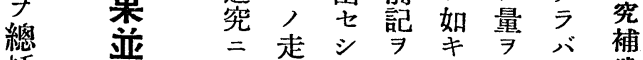

括 三行么方方霄約遗

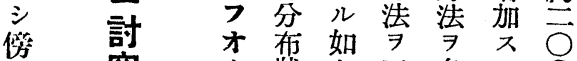

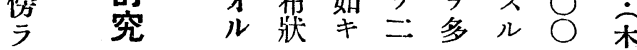

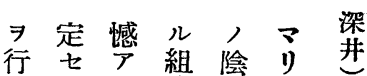

臨屍ド織影竞

床體已捕 $尹$ 品

的 $\exists$ 寻提 次股

所り用 ス 第靜

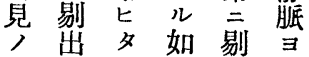

再セりキ出り

檢儿。方音注

討肺更法 テ 入

～臓

忘余聊圍定

夕動 八意狹、七

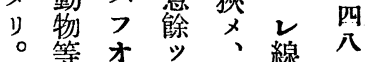

ヨルテ逐撮

用子記二影

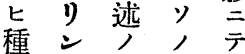

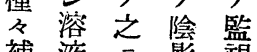

䙏留云影視

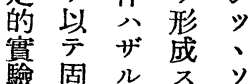


厶糧 心臟

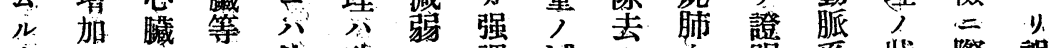
事七, 餘殆 シ調減七血明系狀際誤

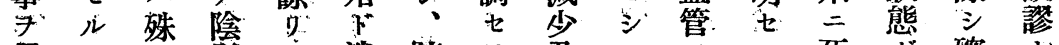
完得 $心$ 影 三消肺

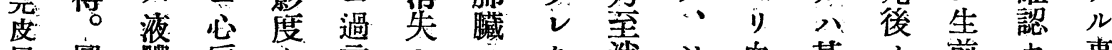
屍圓體房贞言 シ

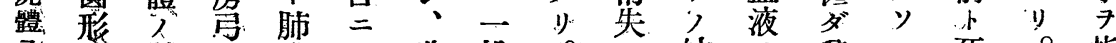

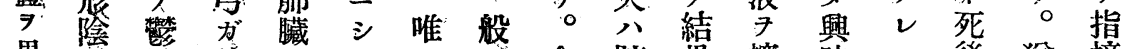

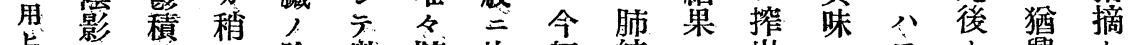

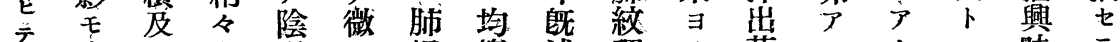
, 亦 ビ 丸影力根等 述 理り若ルタ二昧 ラ 肺減 含 昧度三部了方肺シ事力於アレ

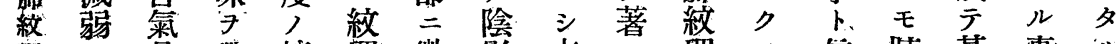

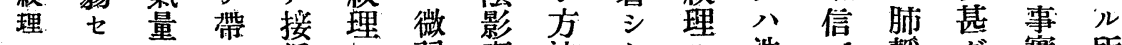

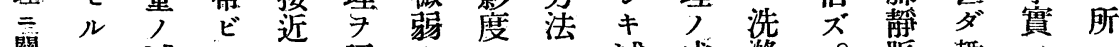
關モ減テ七認ナ示二減成滌ㅇ.脈趣八二

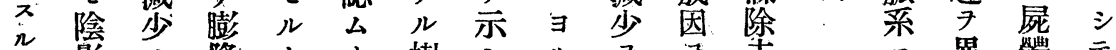
研影了隆々上樹 シ ル 77 去 異體テ

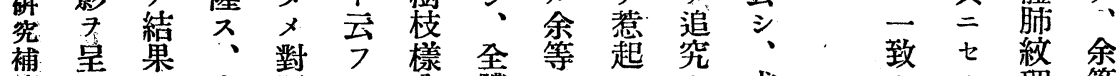
遺

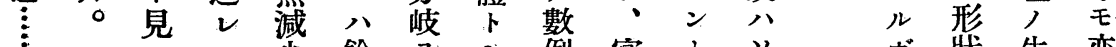

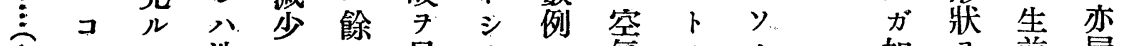

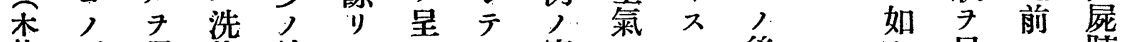
崎環 得 條 結二ス八實 7 ル 後 $キ$ 呈二肺

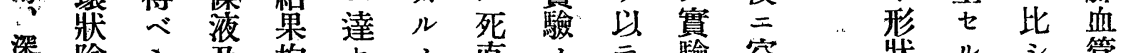

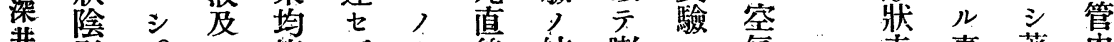
并影。等ザ、後結膨八氣! 走事著内 心肺固化ルナ撮果隆既 $尹$ 行ナ方殊

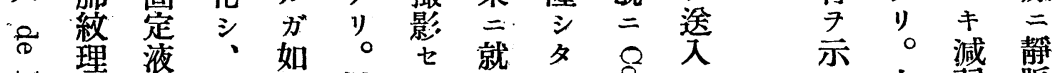
ゅ, 摸 周 㵔 糊 牀 周 モ

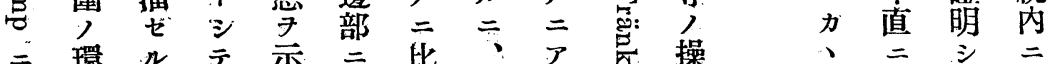

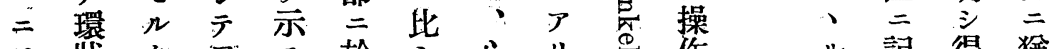

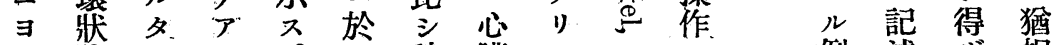

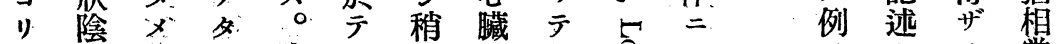

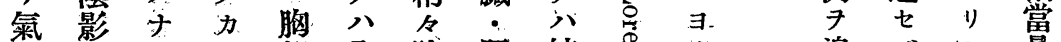
七管 バリモ 部全陰肝紋焉りリ追バ'シ量 四枝稍。玻像另影臟理 等 血 究生三主

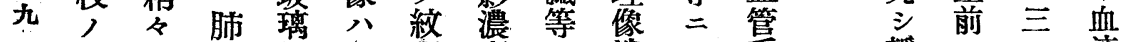
乙不野細全理度人渻妇系静, 方夜

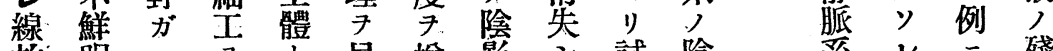

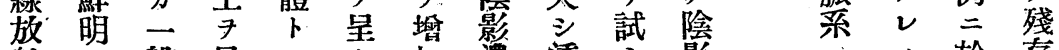

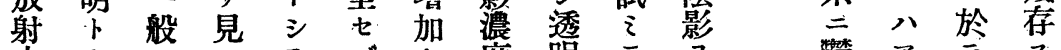

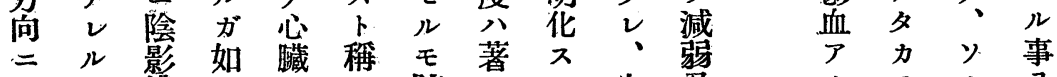

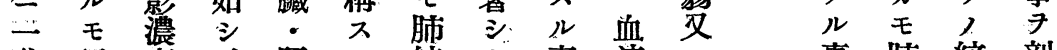

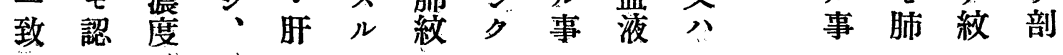




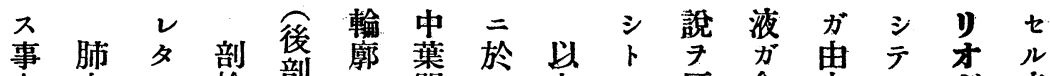

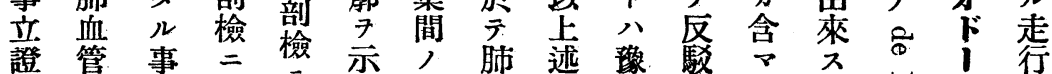

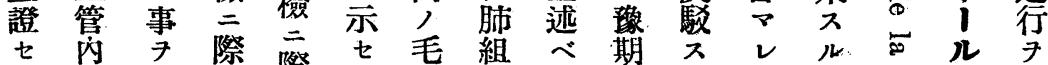
ラ 二 示

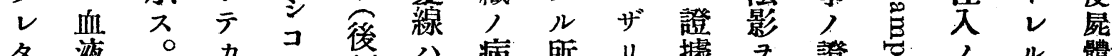

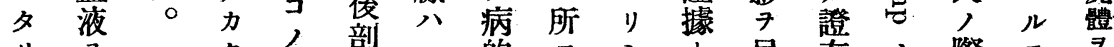
リ ク 部檢 $\rightarrow$ 的 $\exists$ 而卜呈左ノ際モ

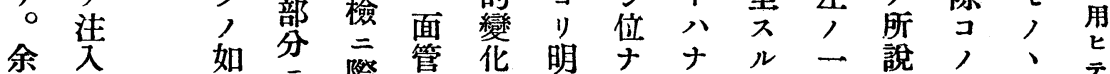

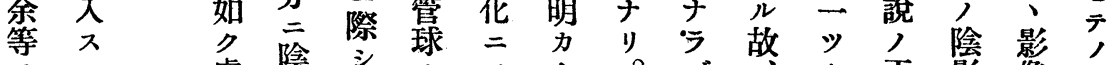

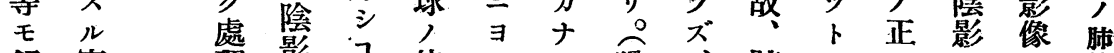

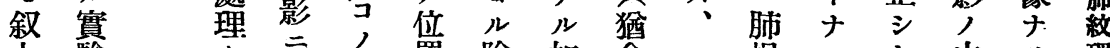
上驗 七相 部置陰如余二根 シキ中リ理

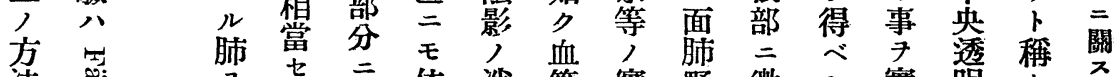
法 突:

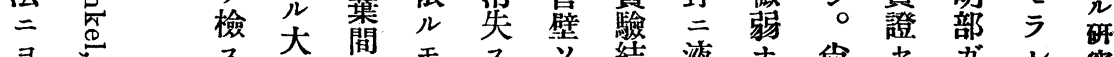
リト ス 惯焉 ニ 及 马灰形認レナノ 殆溜䓩驗血七 試ビ 色 穴

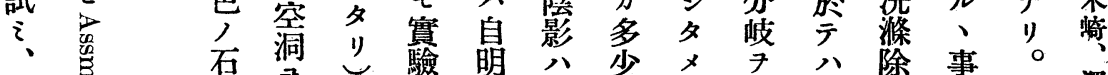

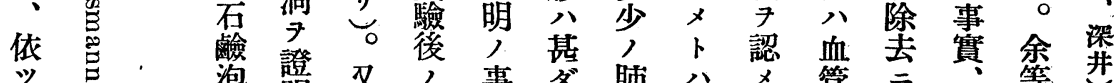
当 テ等

得二

タ 寻

ルリ

像 試

7 i

觀 ラ

察 $レ$

ス

二、結

萢明登? 事多肺

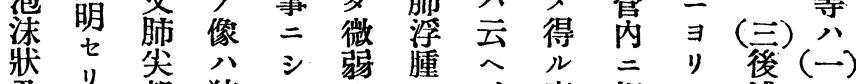

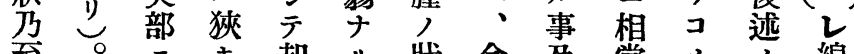
二 却 牀余及當了, 線 於 帶 $\bar{モ}$ 態等

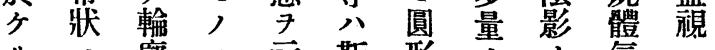
ル 部二示斯形父人氣二 小擴鮮過七臀生消管 指大明ギル, 影理先椟ル 頭 シ 化ザタ 如唯的七造追 大且七ルメ每食ザ影究

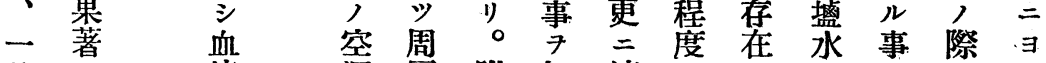

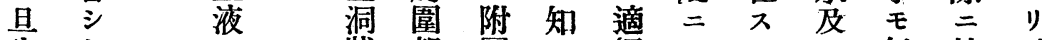
生 キ 前 肺 紋

像 理

比翼

シ 强 著

㪇

牀部圖り切

洗 シ 來

充

陰 二 得ナデ事「管少(二 影對例心肺等 几枝儿生 モ $三$ 三追紋 $匚$ 壁所體 明鮮於。陚理決 $1=$ 見氣

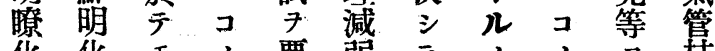

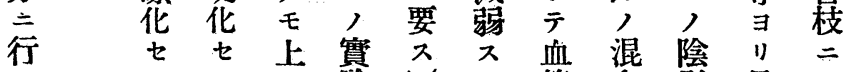
七 吾 


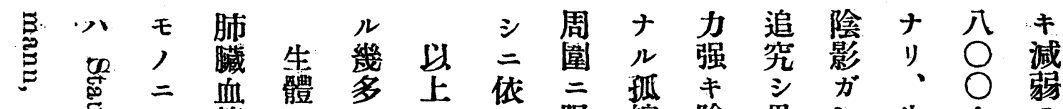

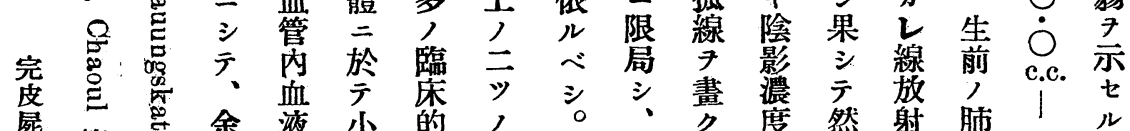

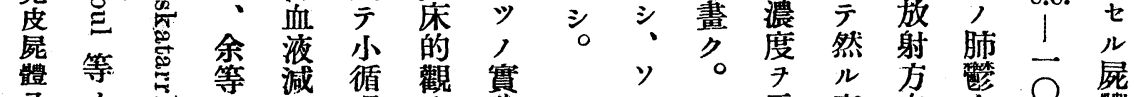
䯈 等 隇 循 觀 實

用記 二㞗少環祭驗 テ 述

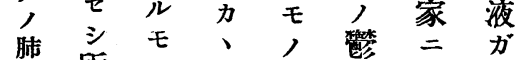
紋所, 向血 $\exists$ 肺 理二ナ例肺状り紋 關 シ 關テ、ト 觀 理 殊

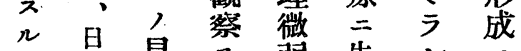
研常䙷祭弱先レ二

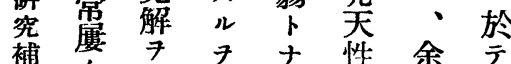

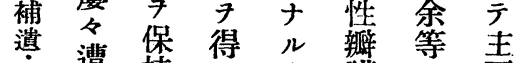
主遇持 事 膜 毛 要

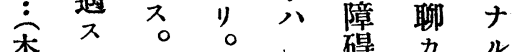
陭所及但点等力役

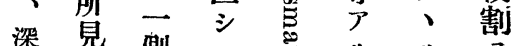

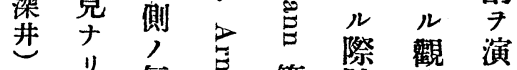
”氣哥等泉憼 演 コ胸怘 際有八指著䉕 尹 茲 几 以摘 方遭 證 緶時上七篦遇 三他如 肺側如々主々モ

臟於管管反”。

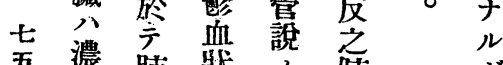

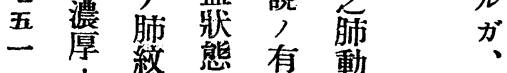

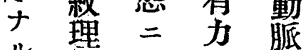

均曙 於ナ瓣

唒

等强兵相品

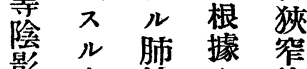

影事絃等

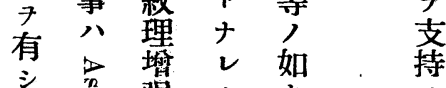

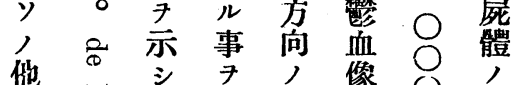
他业 7 , 像 01

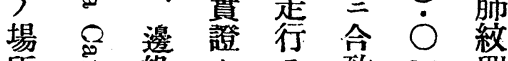
所 总線. 七 $\rightarrow$ 致 c.c. 理

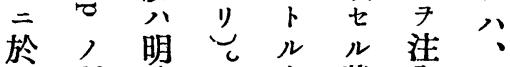
テ所確 肺置 獎 入 揹 認依對理陰ナ時血

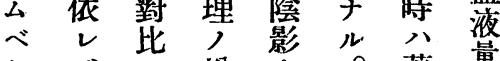
キバ 㯲ナ。著量

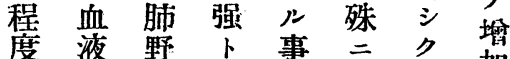
度葆野占事脩奛妿 陰 肺對 時 既 牀分共 影 血 シ 二, ナ共 蜆管 示 中周知形樹 再 七゙注。险事影牀次 卜 入 旰 晾事影狀第

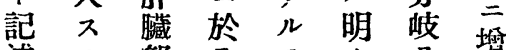
述事部示兵务示强 ル 陰右余俪主

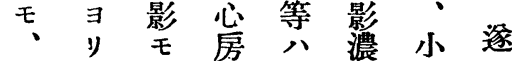
恐著苍更度ナ二 亏越人有等

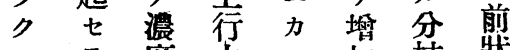
コラ度劣、加枝獎

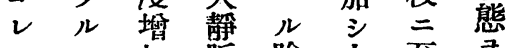
八加脈陰大至 7

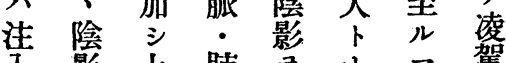

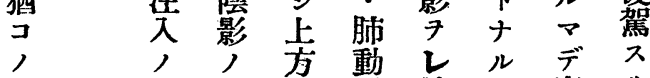

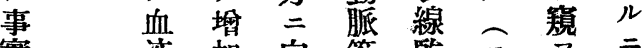
實液加向等監

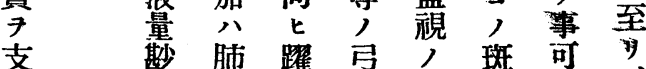
捜分根動弧下鼎能 


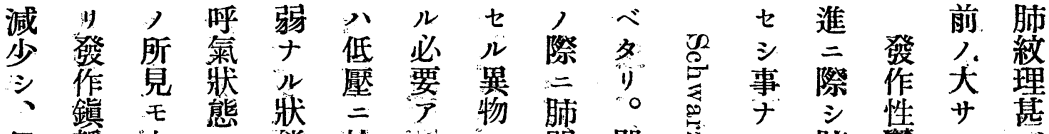

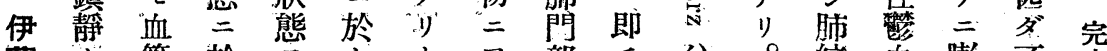

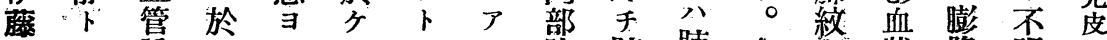

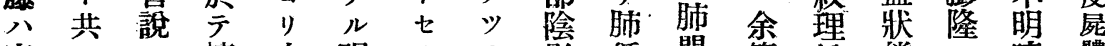

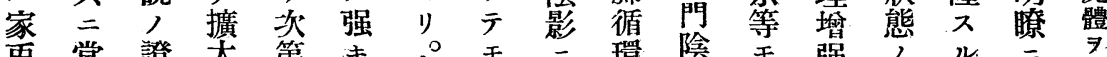
兔党 證 第 キ

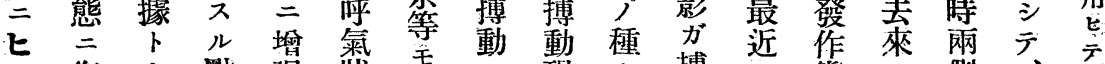

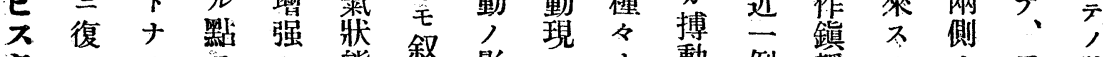

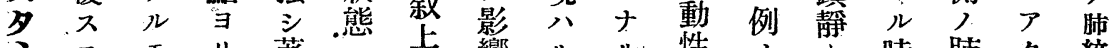

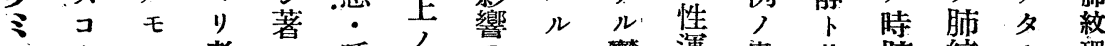

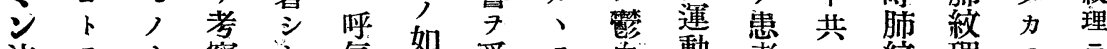

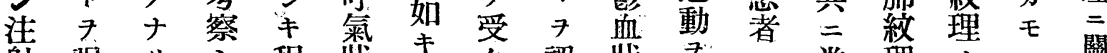
射强り少程牀患名認牀 7 常理, 学關 ナ 調 辻血度 態患動

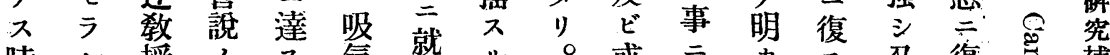

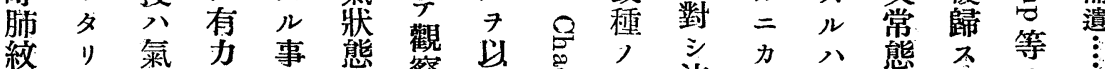
埋 。

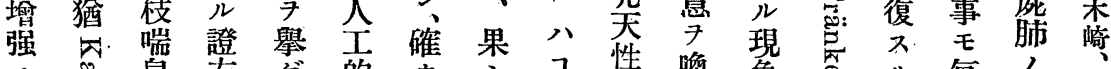

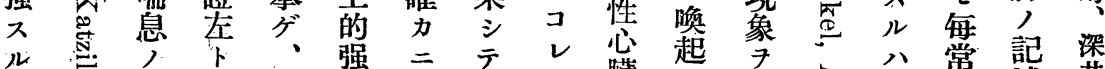

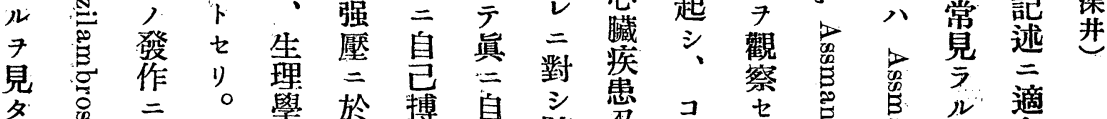

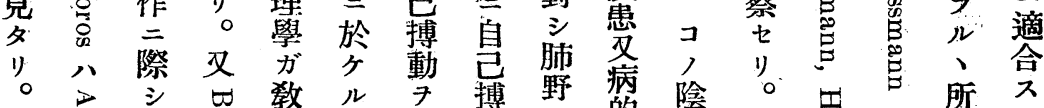

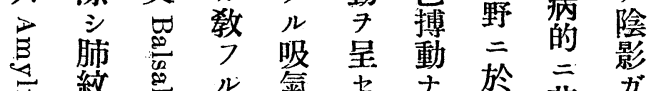

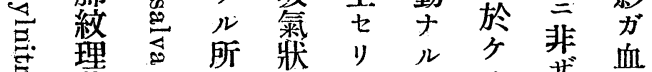

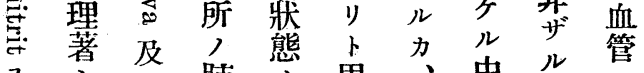
7 シ ビ肺思、中䓌三

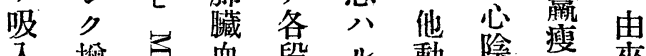

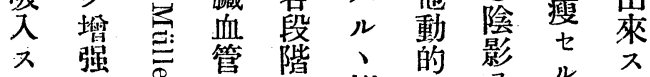

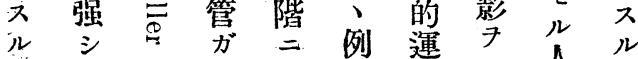

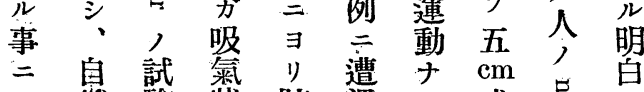

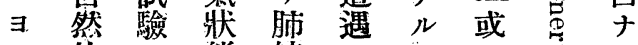

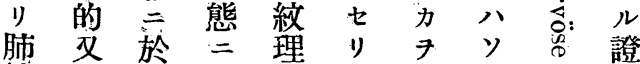
紋心分於分。充儿田明

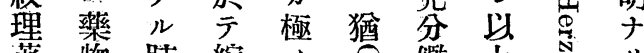

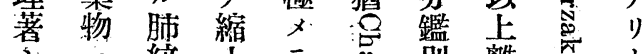

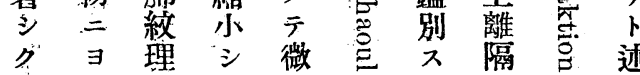

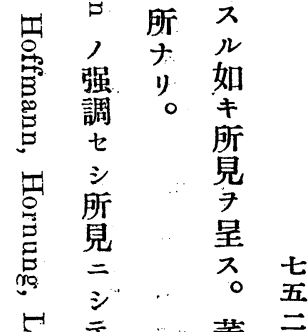

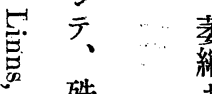
繁部 等 性: 分 要 觀愫旨 


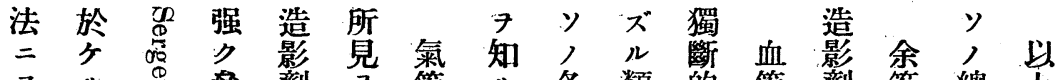

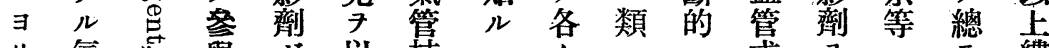

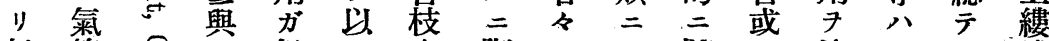

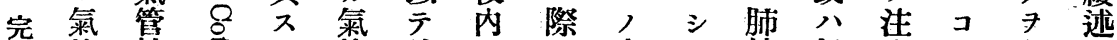
管枝变占管彼三走走紋氣入, 以隹 虚枝 分 表枝等 最テ行、理管し 點 體内布气張内人初モ形コ成枝線 $7=$ 狀 用 難態 四、流管影如幅 兩三人二究卜空

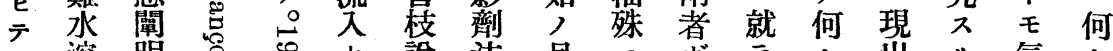

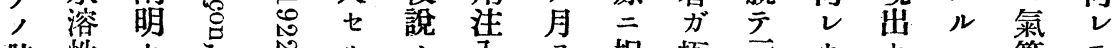
肺 性 $七$ 相云力 䍃 造

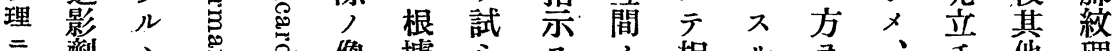

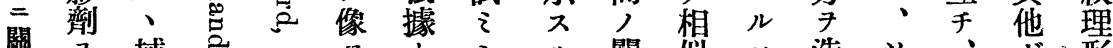

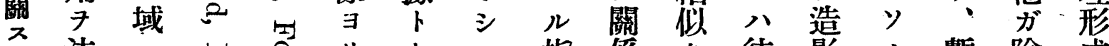

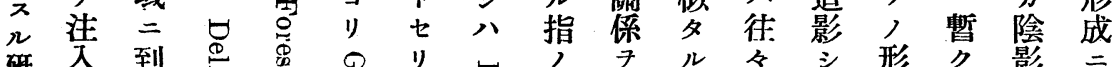

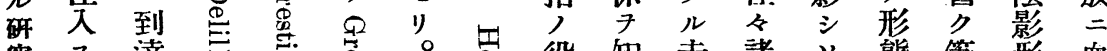

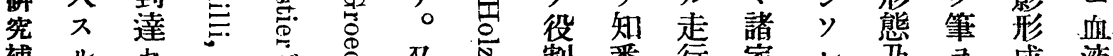

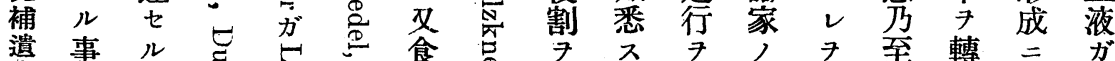

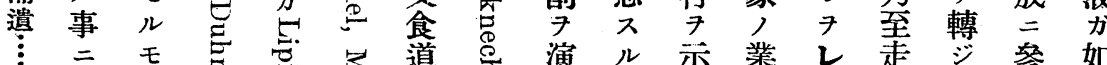

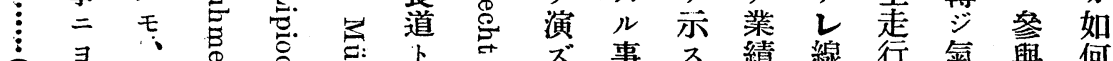

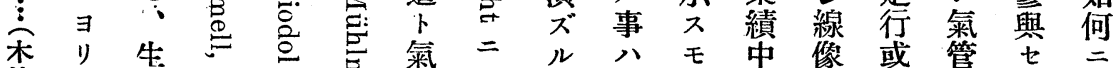

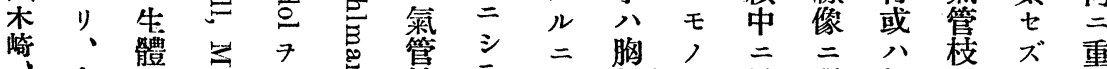

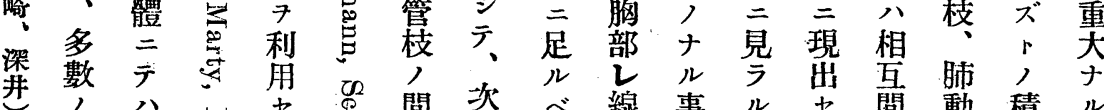

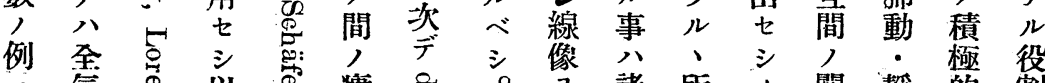

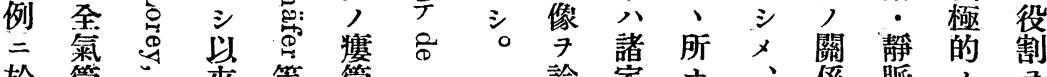

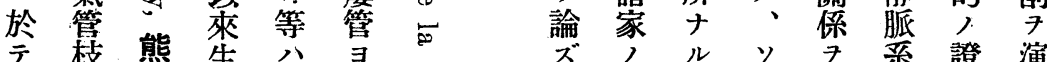

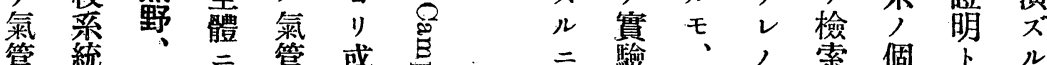

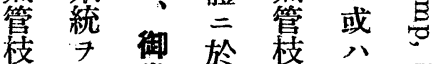

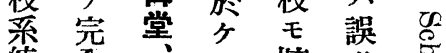
統全村儿肺等 人场氮紋 $\overline{\bar{\sigma}}$

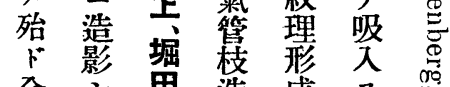

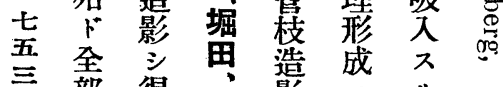

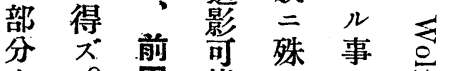
卜界能 目余等 5 肺 $\exists$ 等

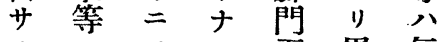

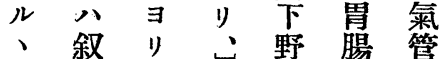

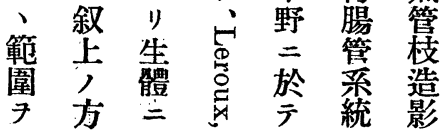
驗, 索個卜 賞二コ肺七公力 》丨八紋儿或ナ 極》云理筫分》極 $x$ 明 7 三警其得 $x$ 可分相結, 公 必ナデ似果内。”明 要电飞三，白 事ナ論 $=$ 言實薪影物 厂, 楯像七統語 肺。片系占花毛 紋然面不 理 27 事。, t

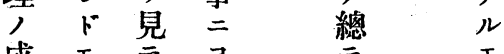

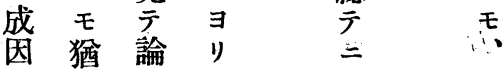




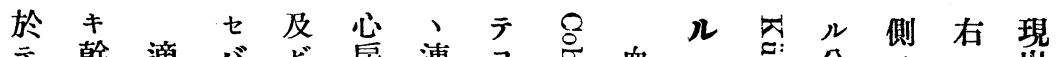

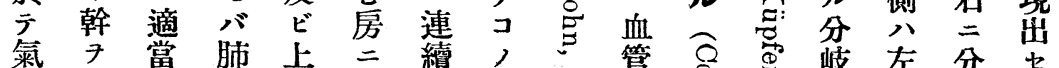

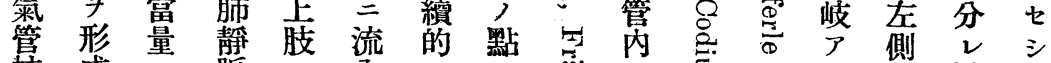

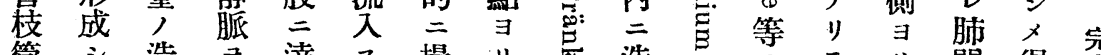
管 シ 造 7 達 ス 撮り廆造

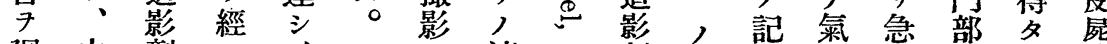

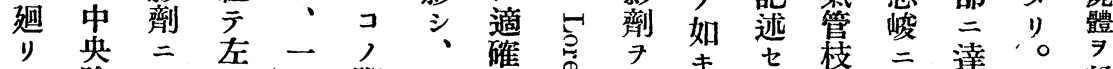
テ陰 $ヨ$ 心 罰影り房右右環儿等入型所造降更手卡

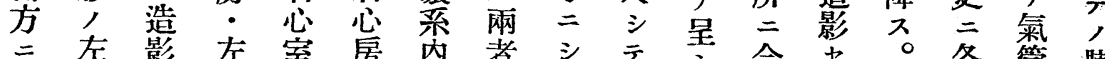

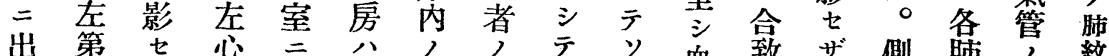

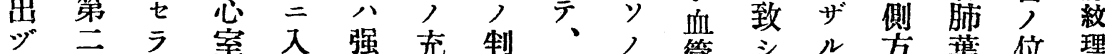

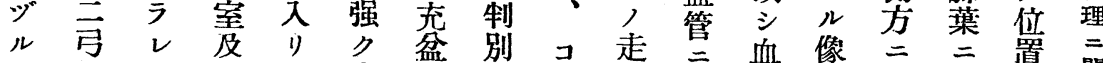
、

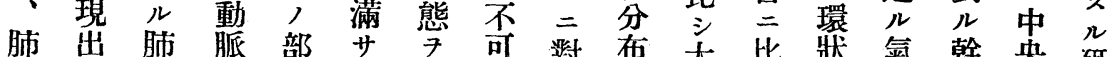

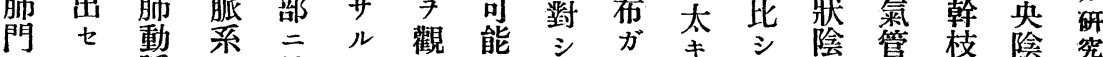

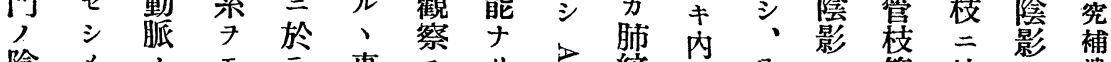

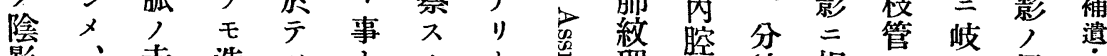

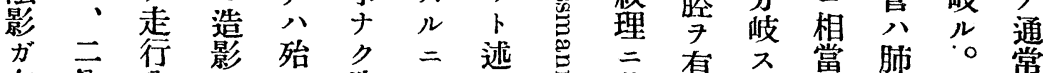

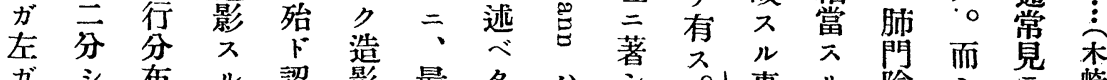

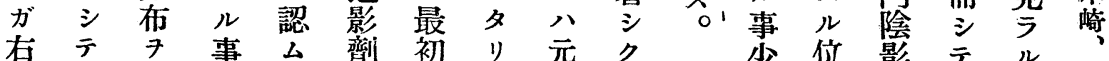

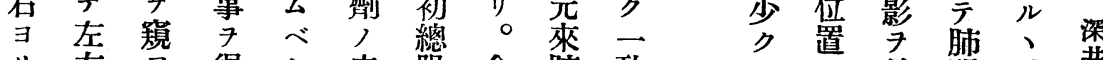

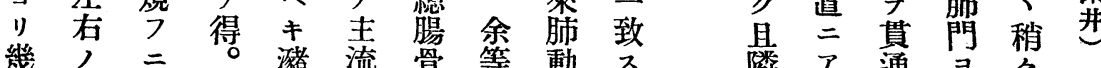
分肺、溜八静, 脈东

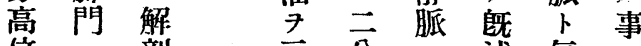
位云剖分穴述氮 至學 $\quad$ 沙下管 少公空方枝血

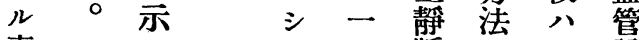
事コス父脈二, y說

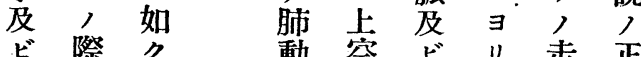

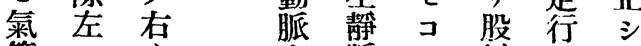

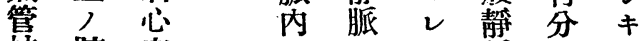
枝肺室 $\quad=\exists=$ 脈㳍重 翰動音”開当著天

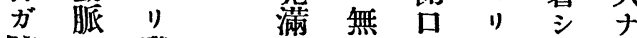
肺分發公多造》 間右 落寻只 影》肺續留永犁致 壬動經注琶子

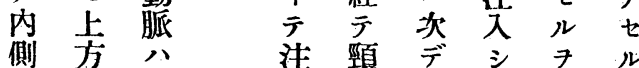
方 短

揆 ” 分。肺明

岐末氣下ナ 部梢管葉 ル 三部枝三帶 至 儿於行儿, $\checkmark$ 中氣部 デル 所管 八分枝一 殆菠 三管致 卢分要要

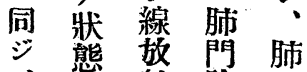
忩䏝㓌門

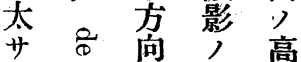

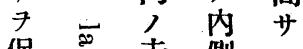
保全側

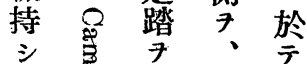
害喜寻右左 


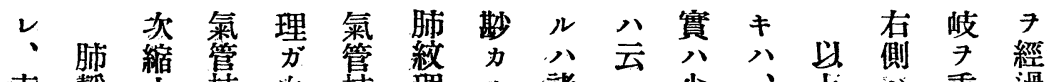

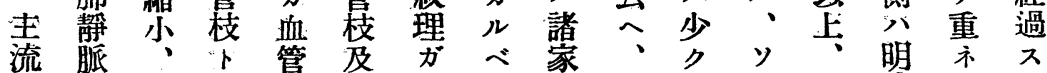

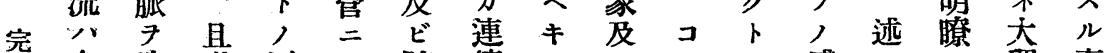

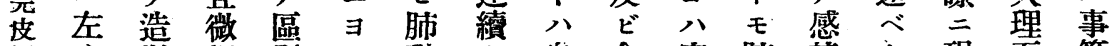
屍心影細別り動七鼻余空肺甚々 現石等

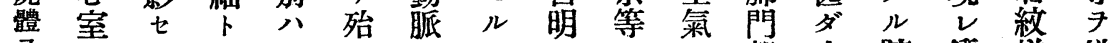

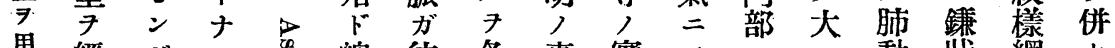
用經 ガル 總往各事實 $コ$ 二

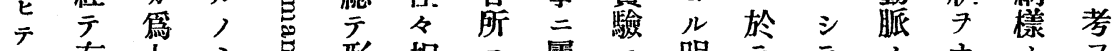
, 左上 $上$ 怘形相二屬二明テテノナノフ 肺心括。方成重於

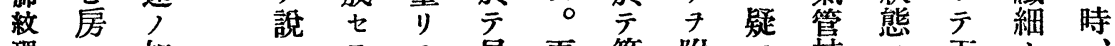
理 三 如 ラ テ見更等附 關達品 如 分 關元股、布 7 余ク

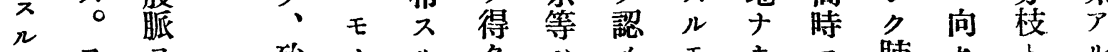

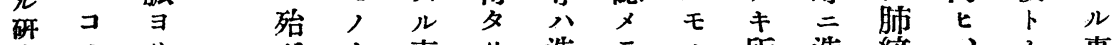

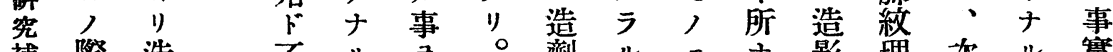

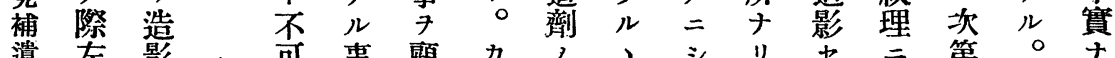
頲左影. 可事顧力, 、

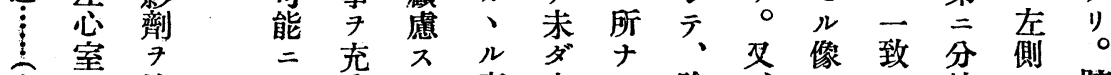

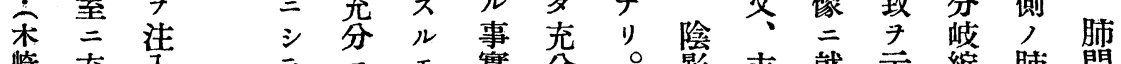
崎充入 示二モ實分。影末就示維肺門

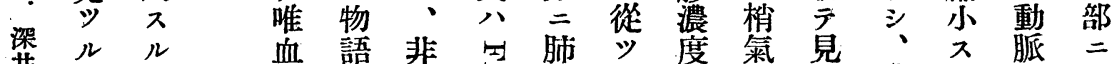
陆量 時 血 語 韭 常 肺

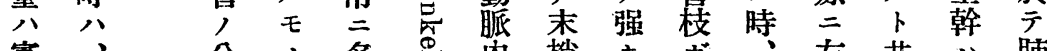

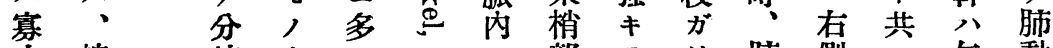
小總 吱

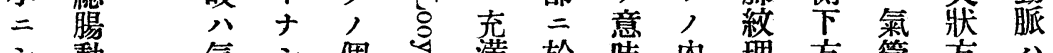

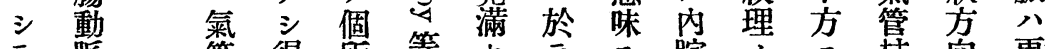
テ脈管 得所 等 七示

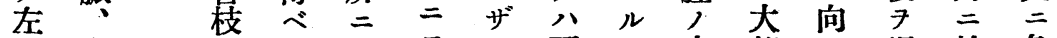

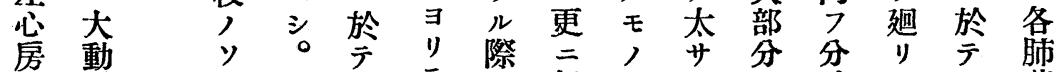
八脈、年、テ氣二三八岐テ小葉

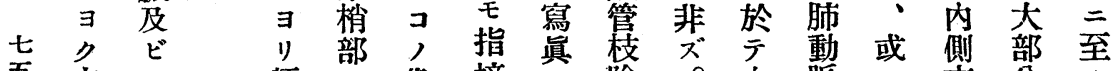

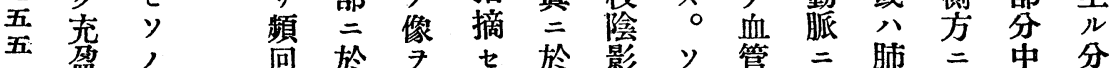
盈人回於 7 於影り管二肺二中分

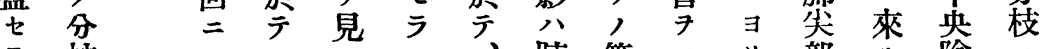
ラ枝 シ ハルレ、肺管 ハリ部ル陰二

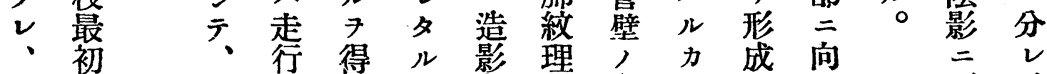

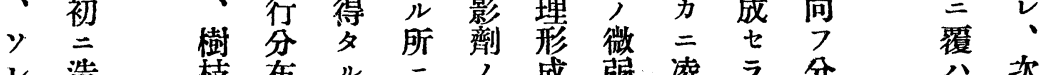

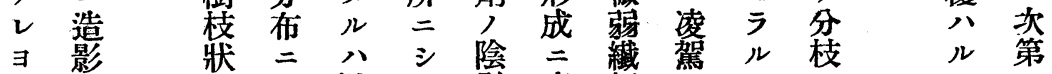

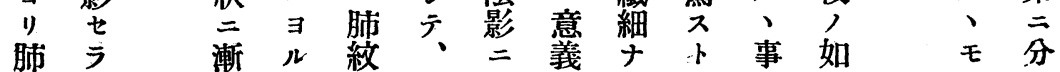




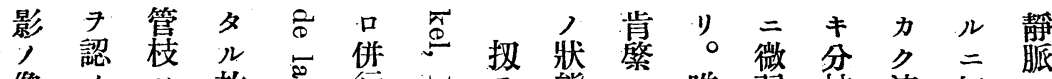

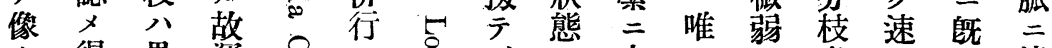

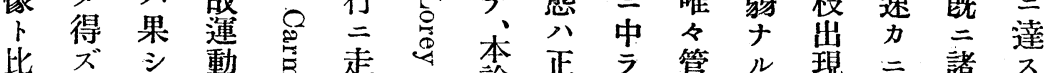

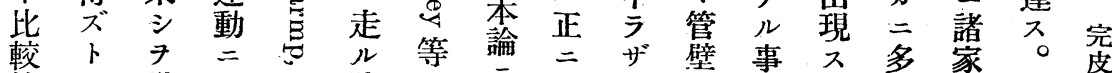

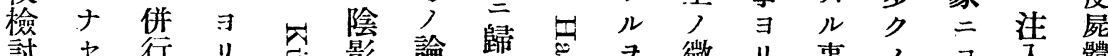

討七行り 哥影諭歸密

シ リ

線余陰

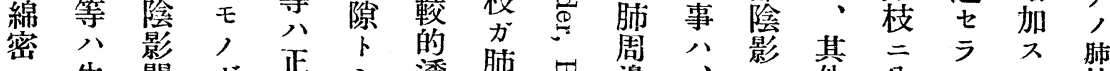

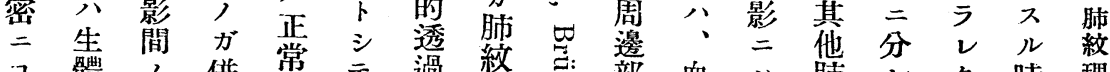

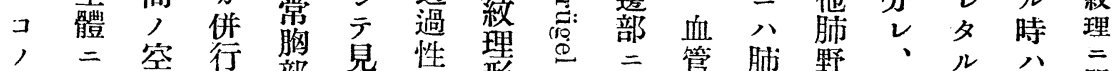

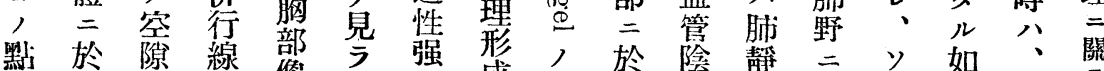

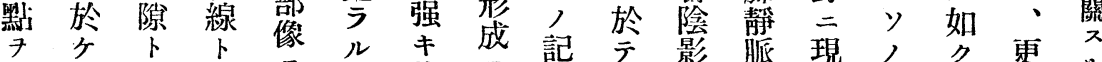

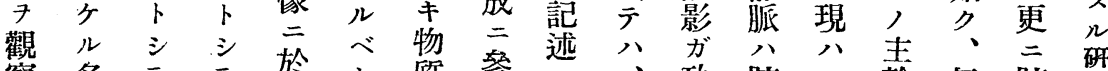
察多數 現出方

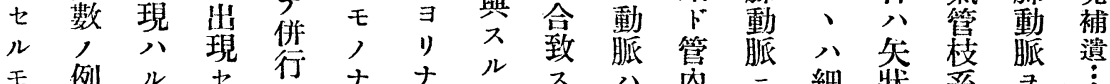
モ例ル セ 梢 屍事 三 走

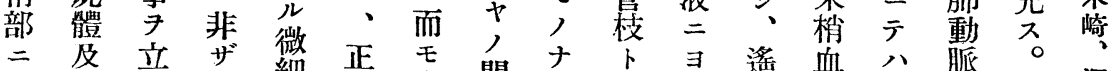
關ビ 證 ル 細 䇛 含 問 ナ

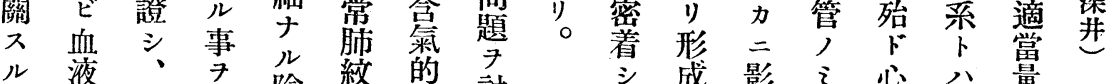

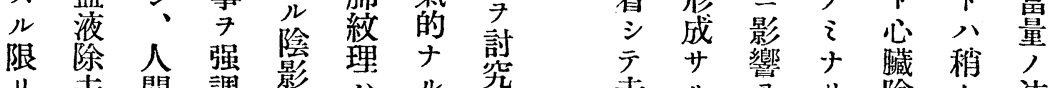

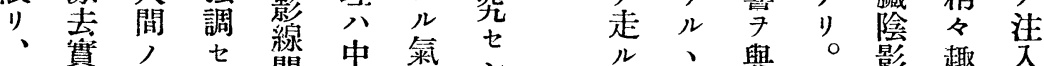

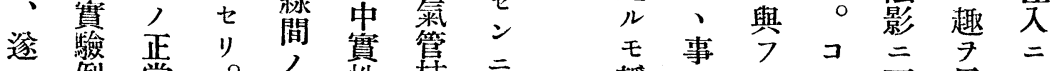
二例常。空性枝二、靜寻东, 覆暴

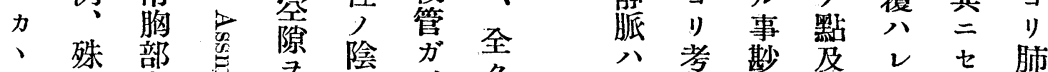

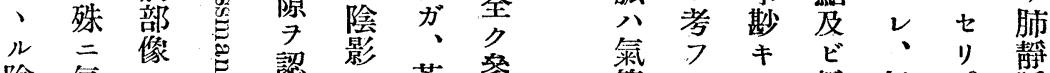

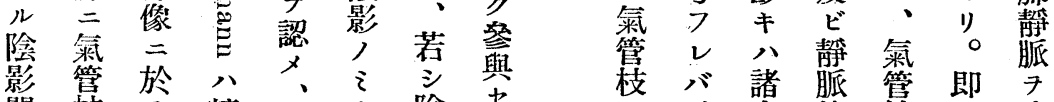

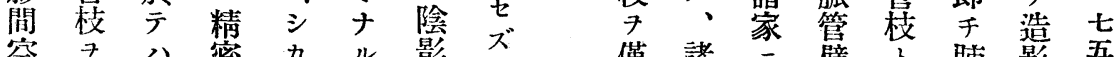

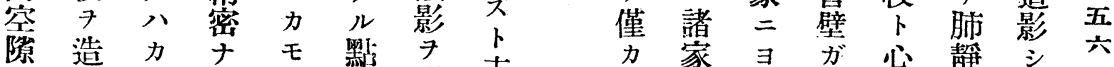

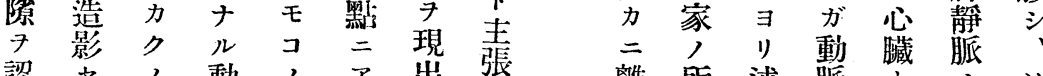
認七, 動, ア出張離所述㟲卜方, メ ル゙ 例桇物 瞬 リ

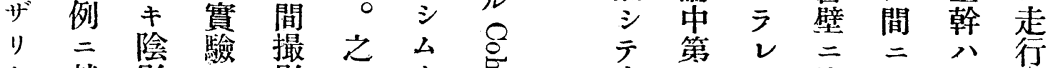
キ 就影二影三

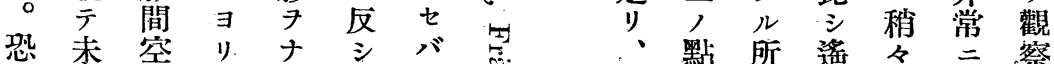

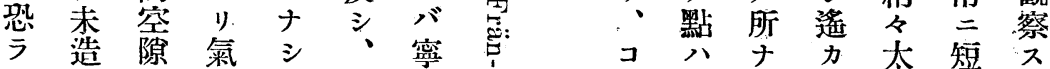


卜於完於卜员影圍レ所了等 ク シ ラ 唒 皮

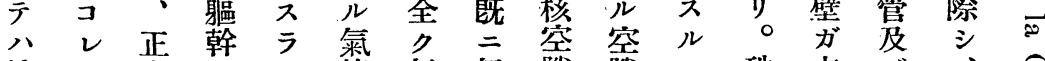

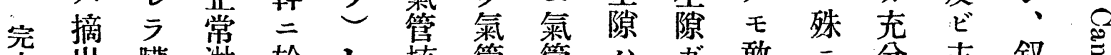

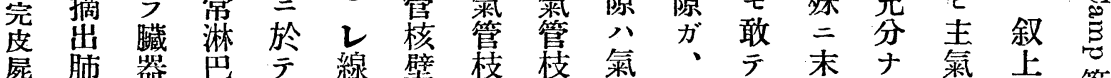

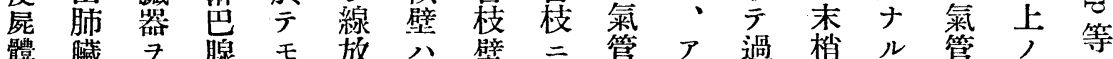
體 臟 腺モ 放八壁二管ア 過梢 ル管了, 等

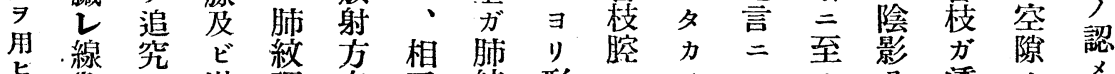

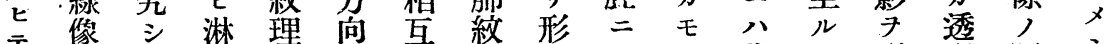

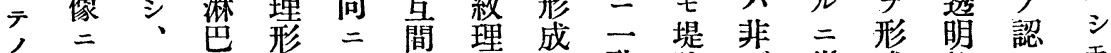
肺於又管成近並形七致防ザ從成部留

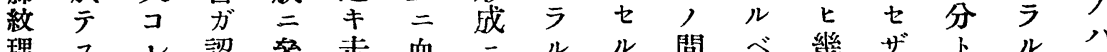
理 スレ 認參走血二ルル間べ幾ザドハ,

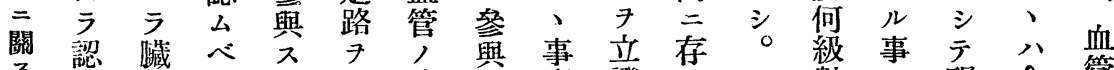
ス 究 キ

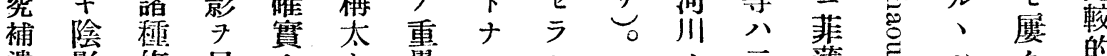

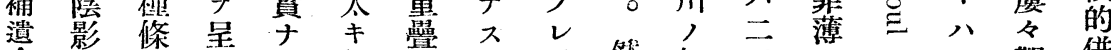

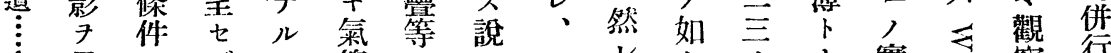

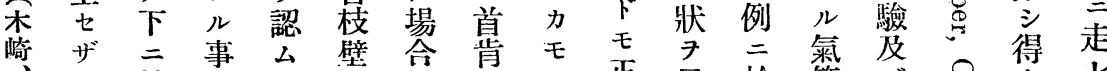

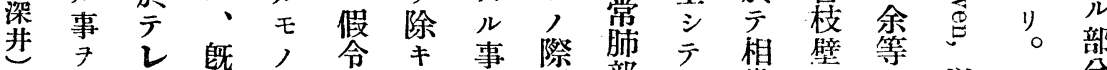
實 線二ナ血認子環部出賞了方上 證撮諸り管台得牀 $九$ 現来 特實 來 七影蒙。陰ざズ陰線七梢性臋明

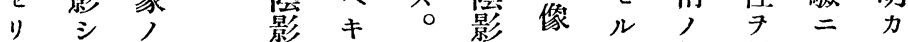
○檢 - 陰 即少 然七致比影于附於認分起り サ $\checkmark r$ t

ト 結 ル

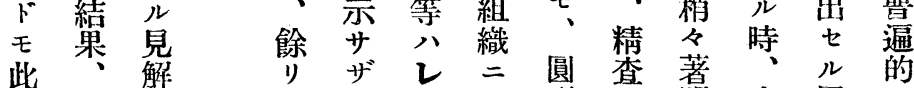
等 正 $ナ$ 線 對形觉奛末屍二 七藏常り, モ事放 シ 結ナ梢萠是 五減鿄。貧 事射相又果儿部二認

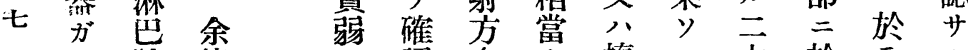

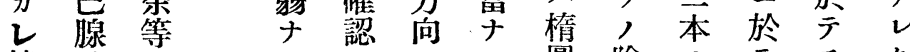

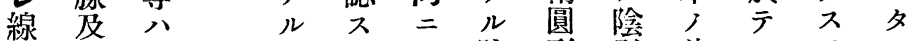
放ビレ程ル垂陵形影並分らル 射淋線. 度毛直影 瀪行陰立所 方巴監 ナ宁濃ナ公影證ナ 向管視剔ル度 ス 氣影 7 七

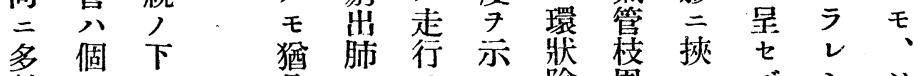
數々 自 = $=$ ス 陰周マズシ】

韭 ザ リ 方 力 唯 病 的 狀 態 即 于 浸 潤 膨 張 甭 
（八）(七）（六）（五）(四）(三）(二)（一）驗

肺正 $テ$ 氣影氧血肺肺肺試等

周常 八管 對 管 血血紋 之 邊 淋 認尔比枝壁管管理 之死

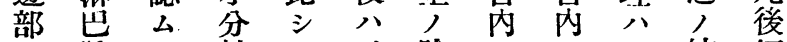
二腺べ枝テ、陰人二主結經 於淋 $\neq=$ 認y影血注卜果過 ヶ巴陰 $\exists \Delta$ 人液入方二時 ル管影 リ 幹肺 肺公 $尹$ 形キ線紋洗儿肺床尠 紋周呈成陰二理 滌血血的 理圍 七七影於形除液管剖完

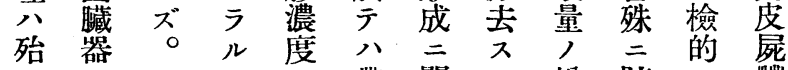
血; ᄀ 示 兆 管對 併

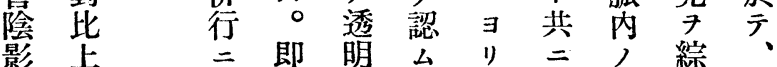
之 合肺占 $\exists r$ 陰 門 三 意理 理 二 正管

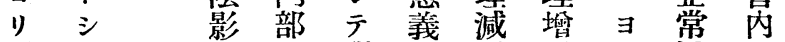
形テ間 二現 $尹$ 弱强》肺血 成八於上有入石形督落 七認空示、年。成理注 ラム腺公り ズ ル 七 二 入 亏 就 及 $キ$
䧔
影
尹
呈
七
ス

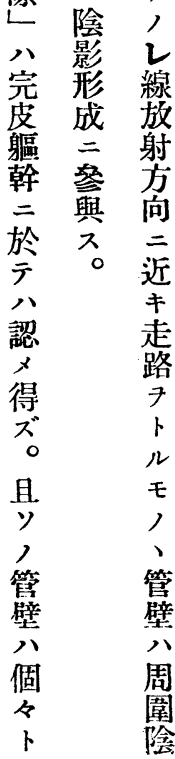

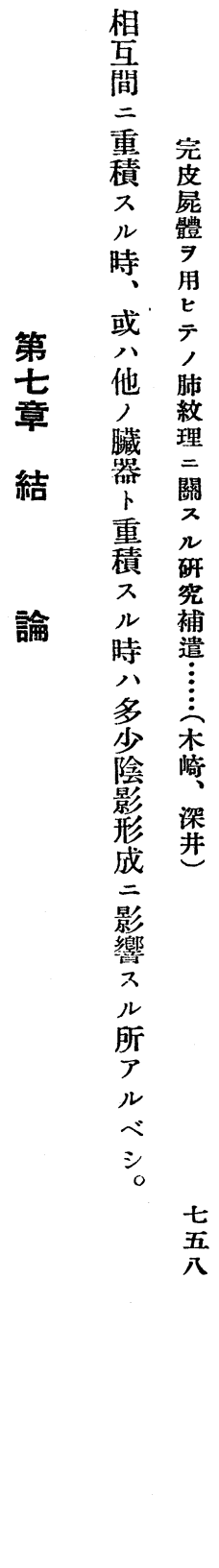




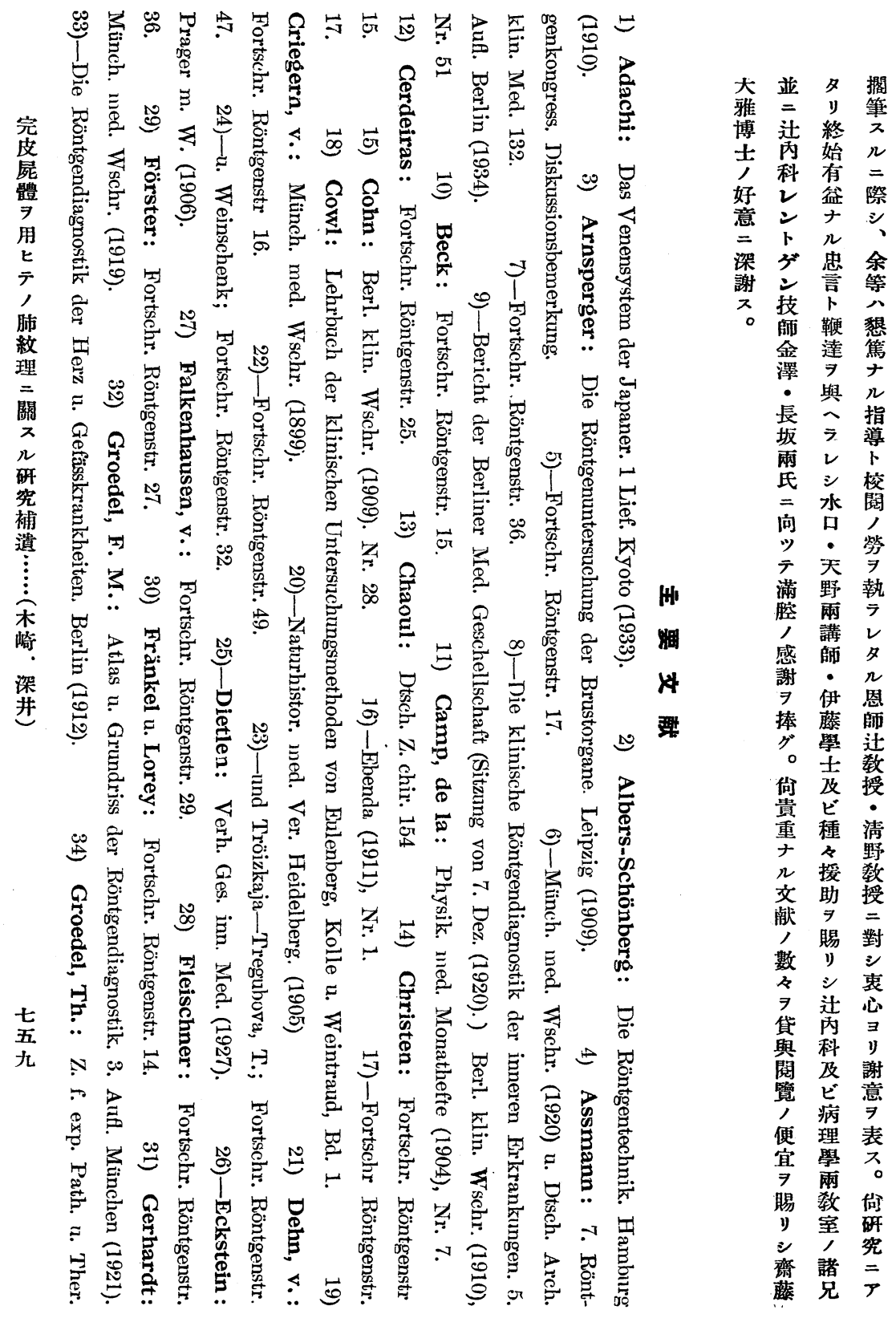



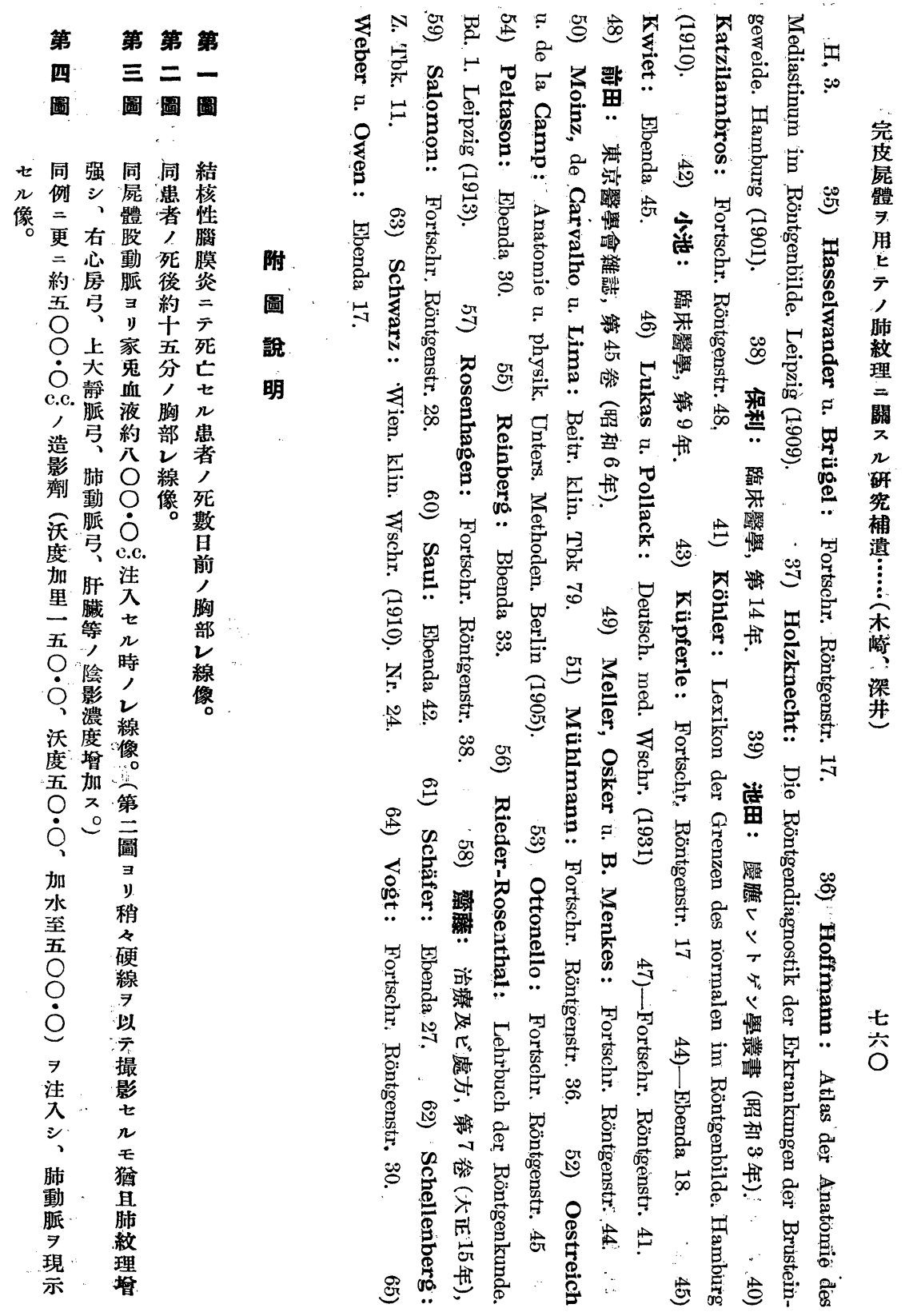
Fig. 1.

木

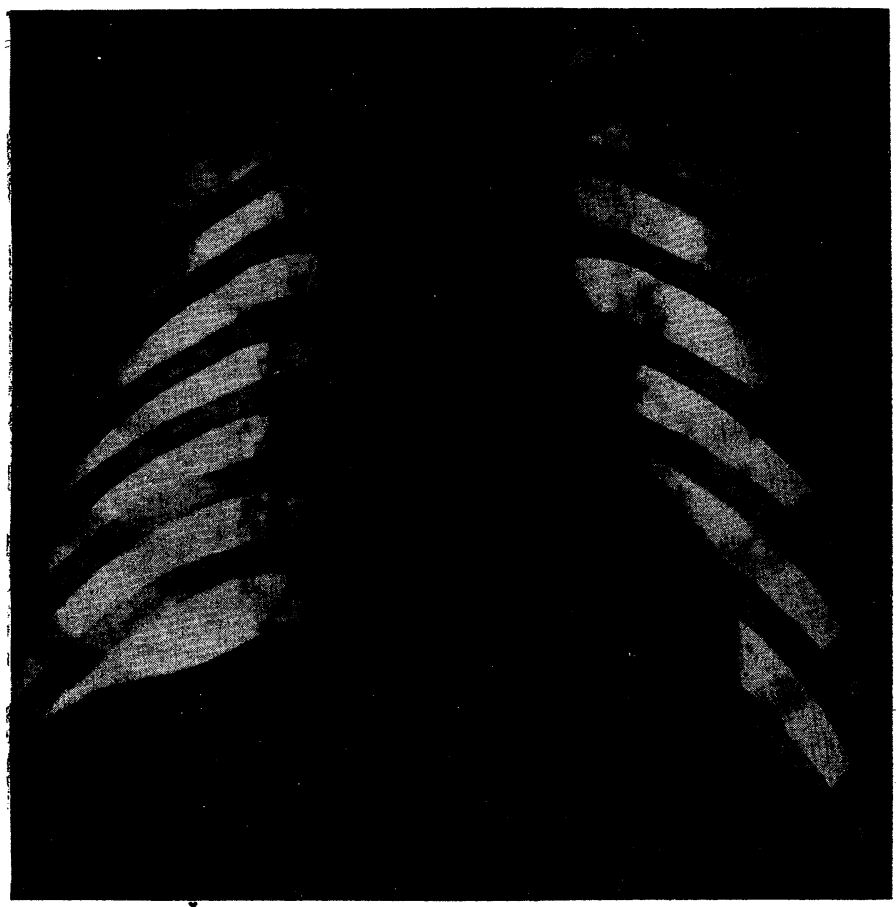

崎

深

井

䜊

交

附

圄

Fig. 2.

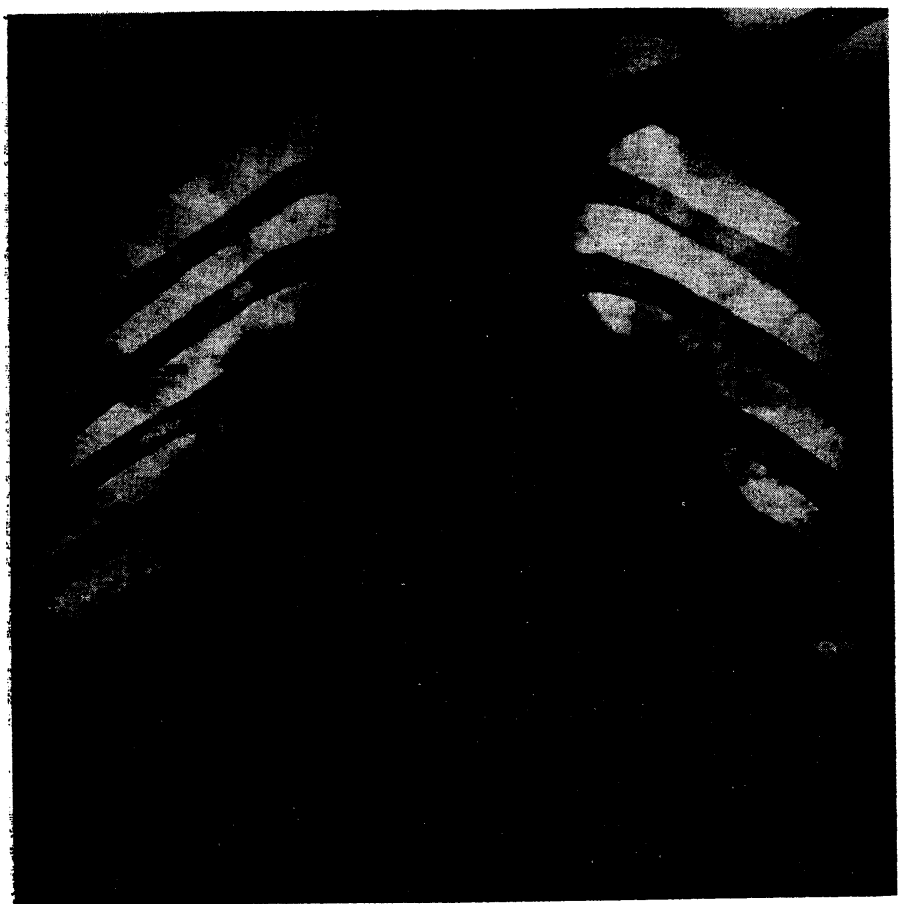


Fig. 3.

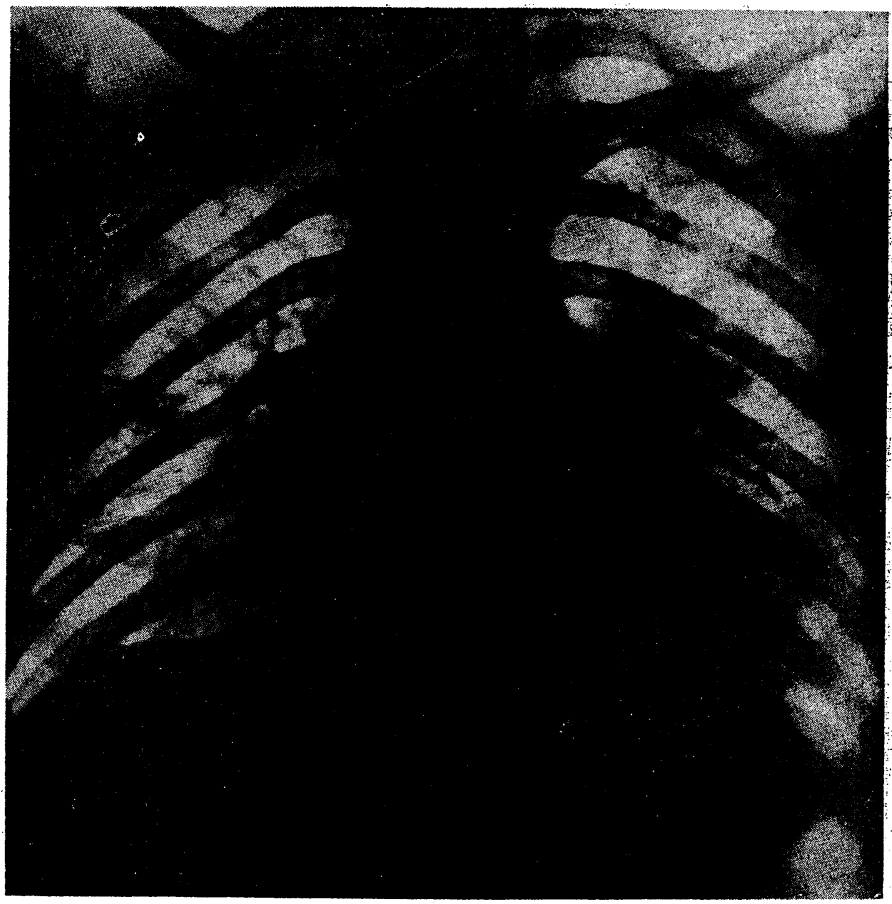

Fig. 4.

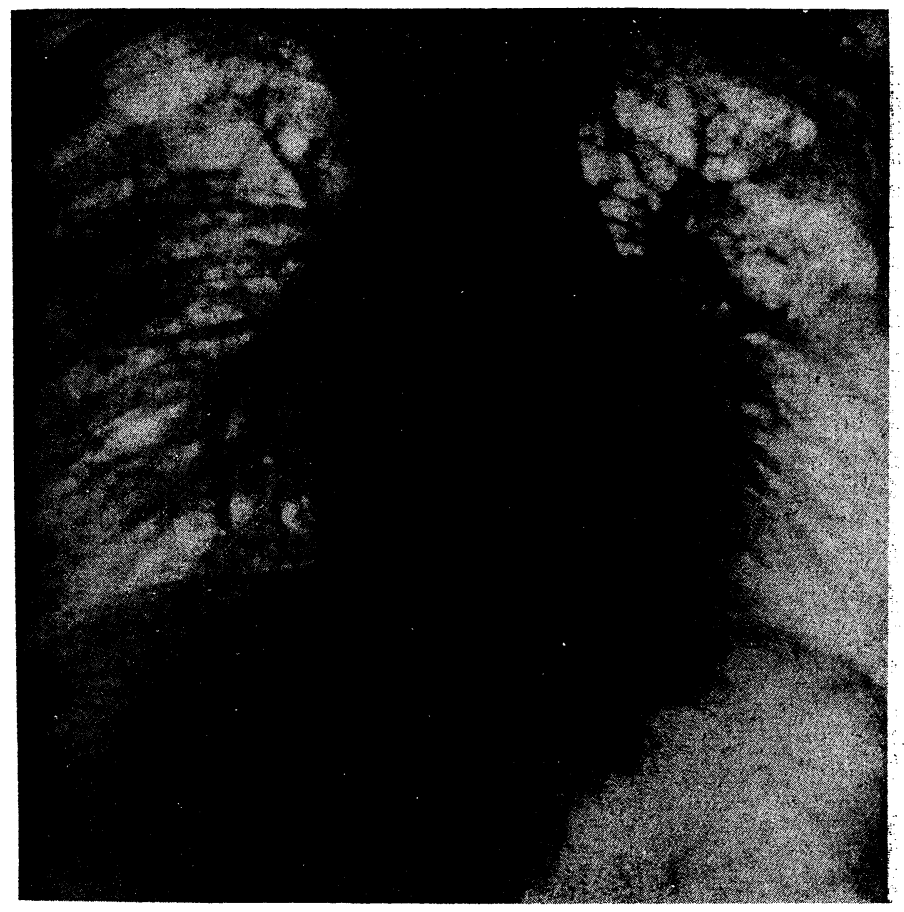


Fig. 5.

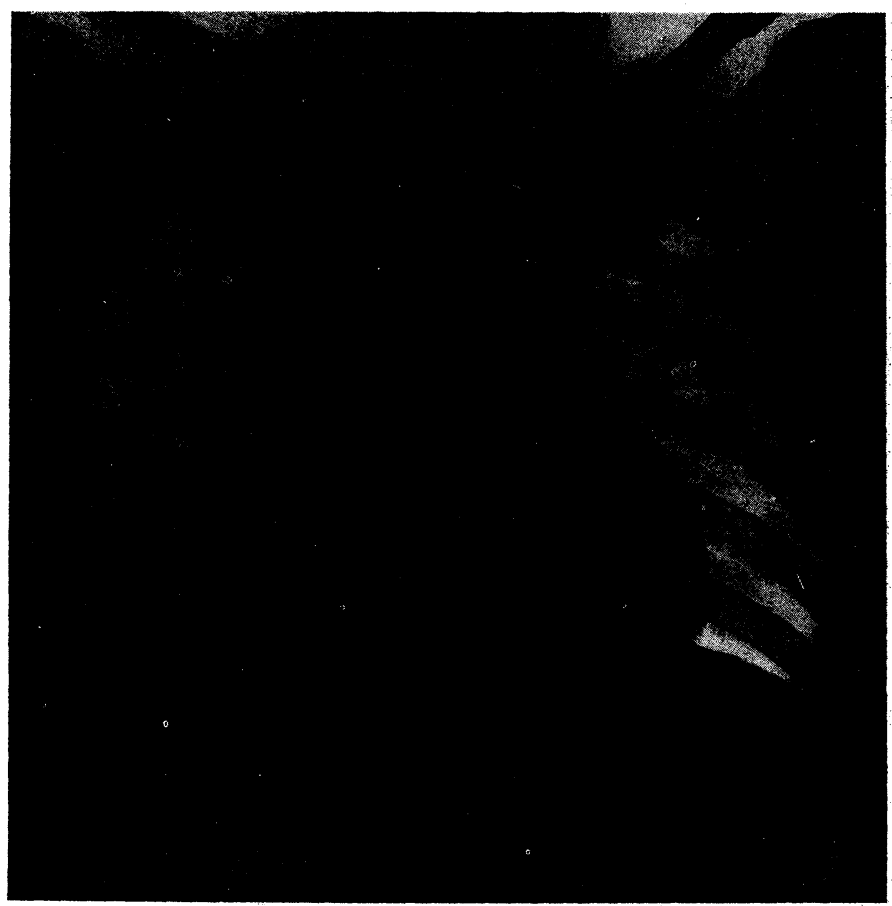

Fig. 6 .

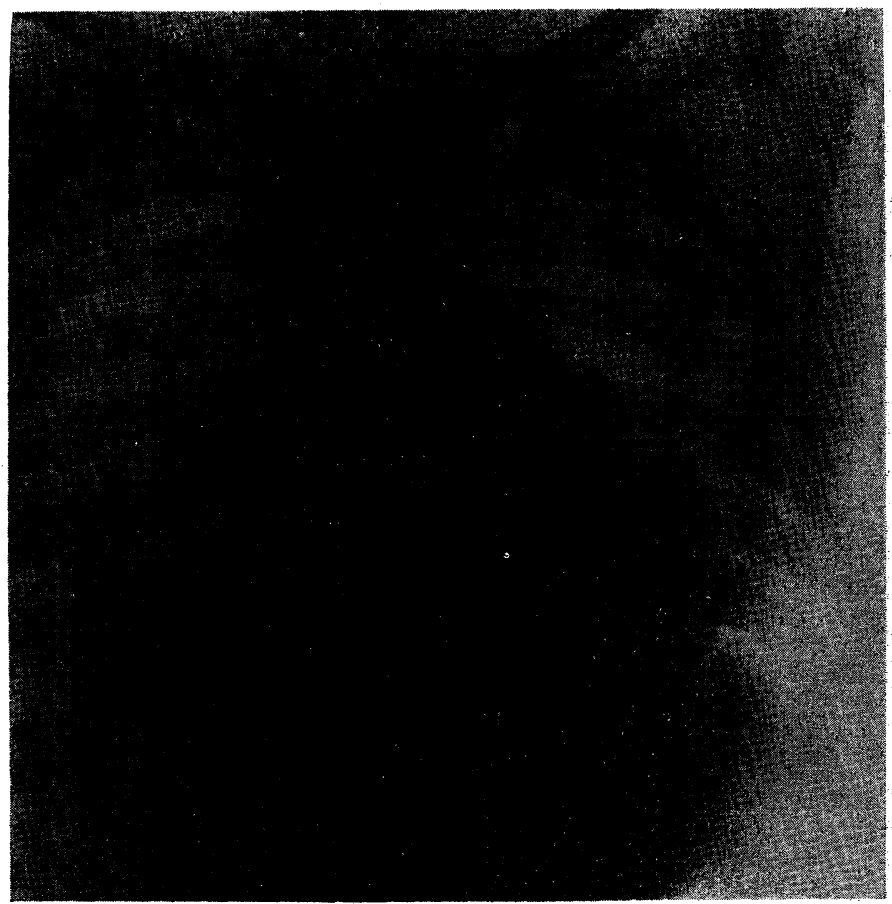


Fig. 7.
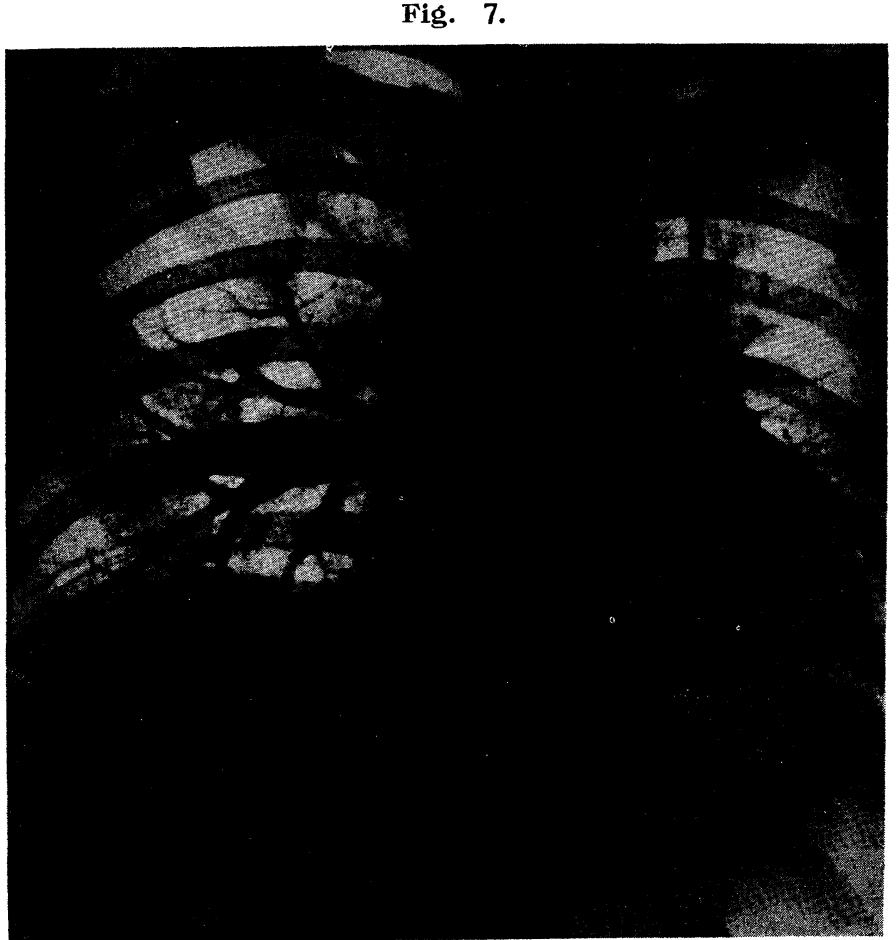

Fig. 8.

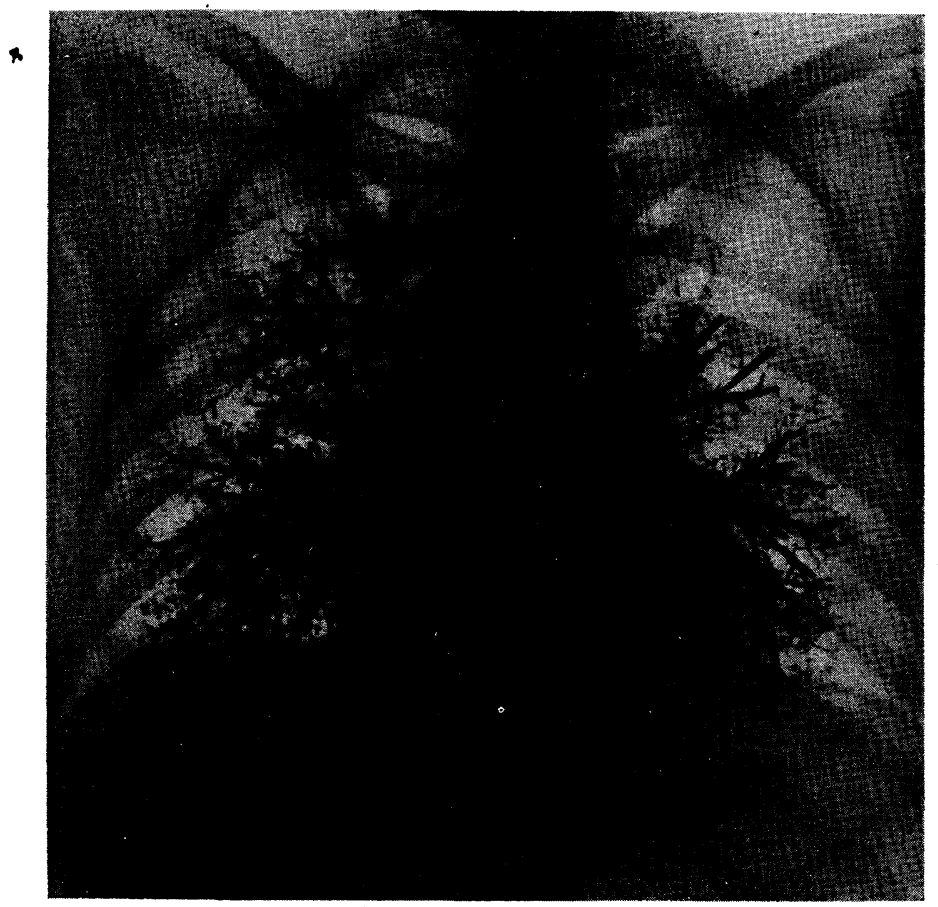




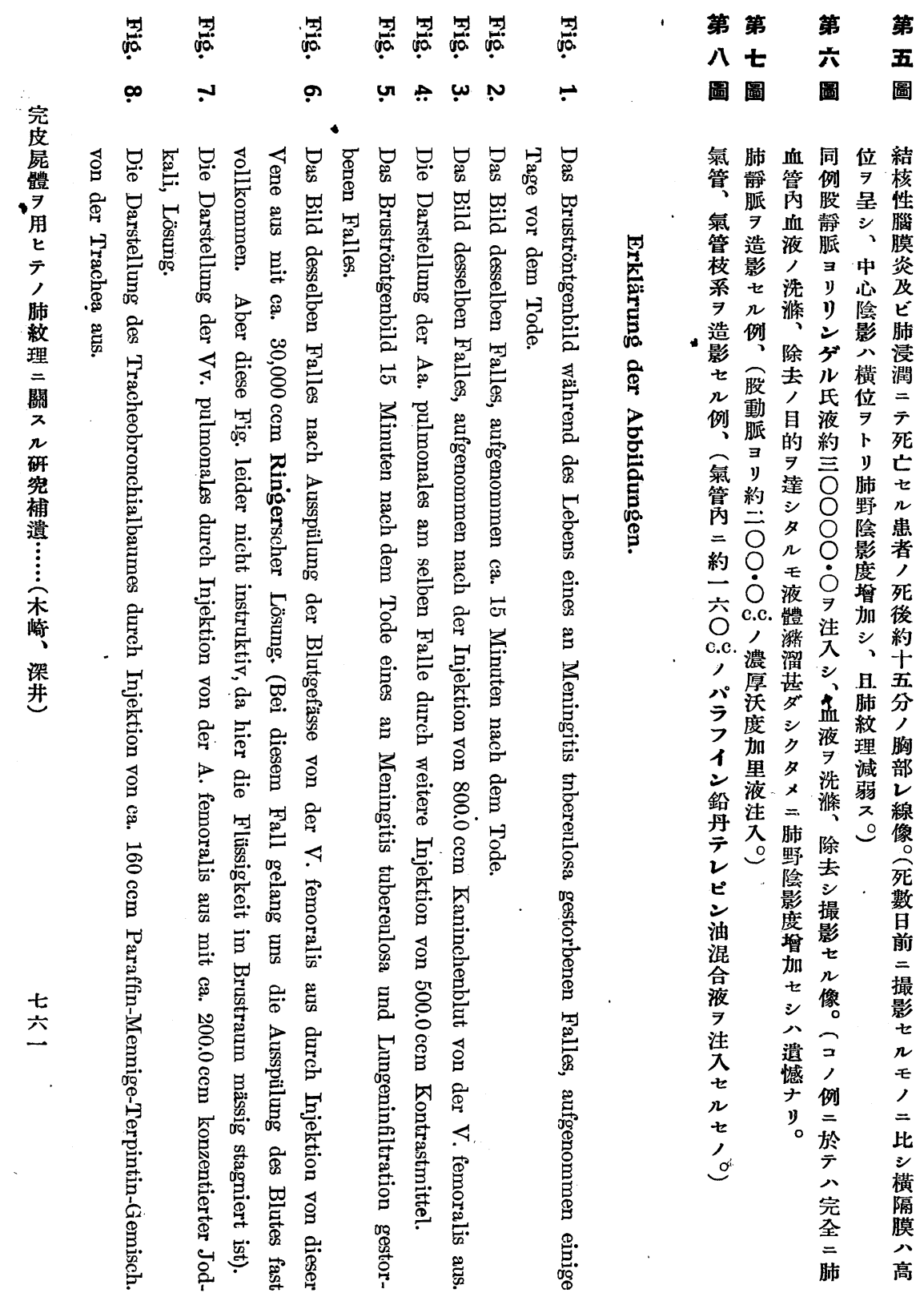


Asthmatikern erhoben wurde. Es handelte sich dabei um 108 Fälle in der anfallfreien Zeit und um 14 Fälle in der Zeit des Anfalles.

Die Resultate sind die folgenden:

1) Blutbild in der anfallfreien Zeit.

a) Haemoglobingehalt, Farbenindex und Erythrocytenzahl waren unverändert.

b) Die Leukocytenzahlen waren ziemlich erhöht.

c) Die neutrophilen polymorphkernigen Leukocyten hatten an Zahl abgenommen, während die Lymphocyten ziemlich vermehrt waren.

d) Die Anzahl der eosinophilen Zellen hatte deutlich zugenommen.

e) Beim Erwachsenen lagen die grossen mononukleären Leukocyten und die Uebergangsformen im normalen Schwankungsbereiche, während sie beim jugendlichen Asthmatiker in der Regel Verminderung zeigten.

f) Die Anzahl der Mastzellen war unverändert.

2) Der Zusammenhang des Blutbildes mit dem Asthmaanfall.

a) Im Anfalle waren die Erythrocyten und der Haemoglobingehalt unverändert, die Leukocyten dagegen vermehrt.

b) Während des Anfalles zeigte die Anzahl der Lymphocyten Abnahme, die der neutrophilen polymorphkernigen Leukocyten dagegen Zunahme.

c) Während der Anfallszeit liessen 5 der 14 Fälle ausgesprochene Eosinophilie erkennen, während 9 . Fälle in der Zeit des Anfalls der anfallfreien Zeit gegenüber Verminderung der eosinophilen Zellen aufwiesen.

d) Die grossen mononukleären Leukocyten und Uebergangsformen und Mastzellen lagen im normalen Schwankungsbereiche.

(Autoreferat.)

\section{Beiträge zur Forschung über das Substrat der Lungenzeichnung an intakten Leichen.}

Von

Dr. K. Kisaki und Dr. C. Fukai. 
(Aus der I. Med. Klinik und der Path. Inst. der Kaiserl. Univ, zu Kyoto in Japan. Direktor: Prof. Dr. K. Tsuji und Prof. Dr. K. Kiyono)

Die Verfasser haben über das Substrat der Lungenzeichnung an intakten. Leichen studiert, um die diesbezüglichen Experimente, die von ihnen und anderen Autoren an ausgeschnittenen Leichenlungen und an Tieren angestellt worden, nachzuprüfen. Dazu fügten sie die klinisch und am Seziertisch gemachten Beobachtungen sowie die Ergebnisse diesbezüglicher Experimente.

Das Gesamtergebnis der Verfasser war dabei kurz folgendes :

Die normale Lungenzeichnung ist hauptsächlich durch das in den Lungengefässen (besonders in den Lungenarterien) vorhandene Blut bedingt. So führt die Zunahme des Blutes in den Lungengefässen zur Verstärkung und Vermehrung der Lungenzeichnung, während die Abnahme des Blutes, z. B. durch Ausspülung, die Lungenzeichuung arm und undeutlich werden lässt. Die Gefässwand selbst spielt bei der Lungenzeichnung keine bedeutende Rolle.

Die Bronchien stellen sich an ihren Stämmen als bandartige Schattenaufhellungen der, während man an der Lungenperipherie den Bronchiolen entsprechende kleine Schattenaufhellungen nicht antrifft. Die Bronchialwände haben an der Lungenzeichnung keinen bedeutenden Anteil. Sie wirken höchstens an Stellen, wo sie grössere Strecken lang in der Durchleuchtungsrichtung verlaufen, schattenbildend. Die Wandungen der Bronchiolen bleiben so gut wie unsichtbar, d. h. an der Lungenperipherie wird die Lungenzeichnung fast vollkommen durch das Blut in den peripheren Gefässe erzeugt.

Die Lymphdrüsen sowie die Lymphgefässe führen unter normalen Verhältnissen allein zu keinen sichtbaren Schatten, wohl aber verstärken sie sowie die Bronchien bei Kreuzung mit anderen Gebilden, besonders Gefässen, den Schatten dieser Gebilde.

(Autoreferat.). 